University of Tennessee Health Science Center

UTHSC Digital Commons

\title{
Neural Crest Contributions to Dental Pulp Stem/Progenitor Cells and Craniofacial Structures: Alveolar Processes, Tongue and Temporomandibular Joint
}

Vinay Jain

University of Tennessee Health Science Center

Follow this and additional works at: https://dc.uthsc.edu/dissertations

Part of the Prosthodontics and Prosthodontology Commons

\section{Recommended Citation}

Jain, Vinay, "Neural Crest Contributions to Dental Pulp Stem/Progenitor Cells and Craniofacial Structures: Alveolar Processes, Tongue and Temporomandibular Joint" (2010). Theses and Dissertations (ETD). Paper 116. http://dx.doi.org/10.21007/etd.cghs.2010.0150. 


\title{
Neural Crest Contributions to Dental Pulp Stem/Progenitor Cells and Craniofacial Structures: Alveolar Processes, Tongue and Temporomandibular Joint
}

\author{
Abstract \\ Background: The cranial neural crest, a transient embryonic structure in vertebrates, is crucial to \\ craniofacial and dental development. Populations of multipotent stem cells have been identified in \\ various dental tissues including dental pulp. Hence, identification of multipotent cells of neural crest \\ lineage within dental pulp and delineation of neural crest contributions to various craniofacial tissues may \\ be a step towards utilizing the potential of neural crest progenitor cells for therapeutic applications. \\ Objective: The overall purpose of the study was to identify a population of dental pulp stem/progenitor \\ cells of neural crest lineage and demonstrate their neural differential potential and to evaluate neural \\ crest contributions to alveolar bone, temporomandibular joint, and tongue using a transgenic gene \\ knockout mouse model.
}

Method: Transgenic mice were generated using Cre/lox system, which produced Cre-mediated recombination resulting in ß-galactosidase (X-gal) staining specifically in neural crest derived tissues, and sections from various craniofacial tissues were analyzed. Cells from dental pulp of these transgenic mice were cultured in a neurogenic medium to assay neurosphere formation and X-gal staining was performed. Wild type mice were also subjected to the same procedures to serve as controls.

Results: Dental pulp cells were cultured for several months. Our analysis demonstrated that neural crest derived cells, as well as cells with mesodermal origin, were present in the cultures and demonstrated positive X-gal staining. Condensation of neural crest derived tissue was seen in the mesenchyme underlying tongue epithelium, dental follicle, dental papilla, nerve ganglia in the tongue cross section, trigeminal ganglion, connective tissue in the palate, alveolar bone, Meckel's cartilage, hyoid bone, hyaline cartilage and the area of TMJ demonstrated the highly positive staining.

Conclusions: This study suggests that: (1) neural crest-derived stem/progenitor cells are present in the dental pulp of embryonic and postnatal transgenic mice, (2) dental pulp cells form neurospheres when cultured under neurosphere forming conditions (Neurobasal A, B-27, EGF, bFGF), (3) neural crest derived cells as well as cells with mesodermal origin are present in the cultures, and (4) neural crest cells contribute in the formation of alveolar processes, tongue and the area of temporomandibular joint in embryonic as well as postnatal mice.

\section{Document Type}

Thesis

\section{Degree Name}

Master of Dental Science (MDS)

\section{Program}

Prosthodontics

\section{Research Advisor}

Christopher Nosrat, Ph.D.

\section{Keywords}

alveolar bone, craniofacial tissues, dental pulp stem cells, neural crest, ß-galactosidase staining, temporomandibular joint 


\section{Subject Categories}

Dentistry | Medicine and Health Sciences | Prosthodontics and Prosthodontology 
Neural Crest Contributions to Dental Pulp Stem Cells/Progenitor Cells and Craniofacial Structures: Alveolar Processes, Tongue and Temporomandibular Joint

\author{
A Thesis \\ Presented for \\ The Graduate Studies Council \\ The University of Tennessee \\ Health Science Center
}

\author{
In Partial Fulfillment \\ Of the Requirements for the Degree \\ Master of Dental Science \\ From The University of Tennessee
}

By

Vinay Jain

May 2010 
Copyright (C) 2010 by Vinay Jain All rights reserved 


\section{ACKNOWLEDGEMENTS}

I would like to express my gratitude to everyone who has helped me in my endeavor of pursuing a Master of Dental Science in Prosthodontics. I am grateful to Dr. Christopher Nosrat, without his immense knowledge and hard work; this research project would not have been possible. I would also like to thank my committee members, Drs. David Cagna, Tiffany Seagroves and Tony Wicks for their advice and experience. I would also like to extend my special thanks to Drs. Akira Ito, Irina Nosrat, Aneesha Acharya and Ms. Michelle Sims for their extensive help and support during the project. Lastly, I would also like to thank American College of Prosthodontics Education Foundation for providing us a research fellowship. 


\begin{abstract}
Background: The cranial neural crest, a transient embryonic structure in vertebrates, is crucial to craniofacial and dental development. Populations of multipotent stem cells have been identified in various dental tissues including dental pulp. Hence, identification of multipotent cells of neural crest lineage within dental pulp and delineation of neural crest contributions to various craniofacial tissues may be a step towards utilizing the potential of neural crest progenitor cells for therapeutic applications.
\end{abstract}

Objective: The overall purpose of the study was to identify a population of dental pulp stem/progenitor cells of neural crest lineage and demonstrate their neural differential potential and to evaluate neural crest contributions to alveolar bone, temporomandibular joint, and tongue using a transgenic gene knockout mouse model.

Method: Transgenic mice were generated using Cre/lox system, which produced Cre-mediated recombination resulting in $\beta$-galactosidase (X-gal) staining specifically in neural crest derived tissues, and sections from various craniofacial tissues were analyzed. Cells from dental pulp of these transgenic mice were cultured in a neurogenic medium to assay neurosphere formation and X-gal staining was performed. Wild type mice were also subjected to the same procedures to serve as controls.

Results: Dental pulp cells were cultured for several months. Our analysis demonstrated that neural crest derived cells, as well as cells with mesodermal origin, were present in the cultures and demonstrated positive X-gal staining. Condensation of neural crest derived tissue was seen in the mesenchyme underlying tongue epithelium, dental follicle, dental papilla, nerve ganglia in the tongue cross section, trigeminal ganglion, connective tissue in the palate, alveolar bone, Meckel's cartilage, hyoid bone, hyaline cartilage and the area of TMJ demonstrated the highly positive staining.

Conclusions: This study suggests that: (1) neural crest-derived stem/progenitor cells are present in the dental pulp of embryonic and postnatal transgenic mice, (2) dental pulp cells form neurospheres when cultured under neurosphere forming conditions (Neurobasal A, B-27, EGF, bFGF), (3) neural crest derived cells as well as cells with mesodermal origin are present in the cultures, and (4) neural crest cells contribute in the formation of alveolar processes, tongue and the area of temporomandibular joint in embryonic as well as postnatal mice. 


\section{TABLE OF CONTENTS}

CHAPTER 1: INTRODUCTION AND BACKGROUND.............................................1

CHAPTER 2: REVIEW OF LITERATURE .............................................................5

THE CRANIAL NEURAL CREST AND ITS ROLE IN CRANIOFACIAL

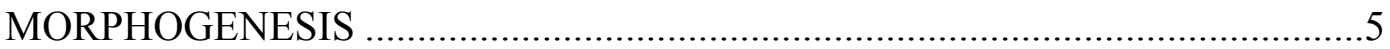

General Aspects and Origin ..................................................................5

Cranial Neural Crest Cell Induction, Migration and Segregation.................6

Multipotency of Neural Crest Cells: Cranial Neural Crest Stem

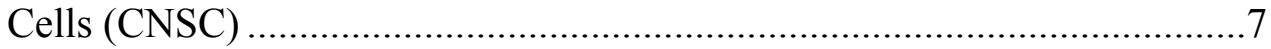

Cranial Neural Crest Stem/Progenitor Cells (CNSC) in Dental

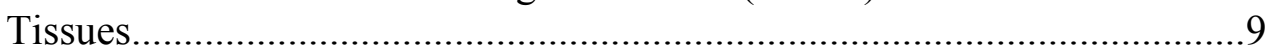

Cranial Neural Crest Contributions to Craniofacial Development ...............9

STUDY MODELS FOR CRANIAL NEURAL CREST CELL BIOLOGY .........11

Classical Ablation Experiments ...........................................................11

Explantation Studies ...................................................................... 11

Cell Marking Techniques................................................................... 12

Cell Lineage Studies Using Retroviruses ...........................................12

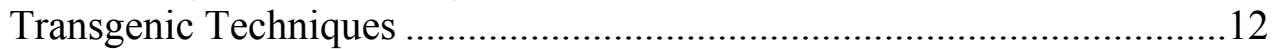

Molecular Markers for Neural Crest Lineage .......................................... 12

Avian Study Models ........................................................................13

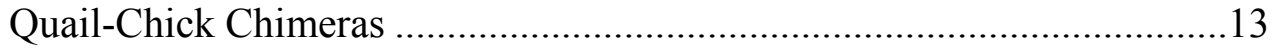

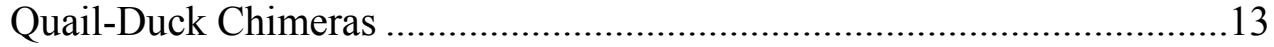

Mouse-Chick Chimeras ........................................................................13

Mouse Models and the Cre/lox System .................................................14

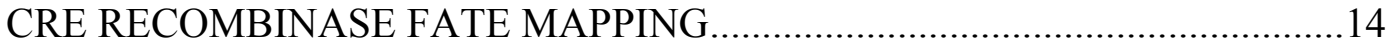

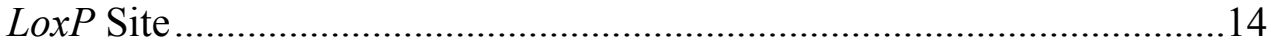

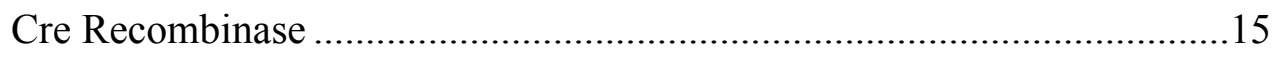

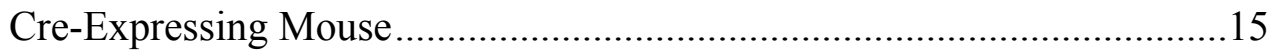

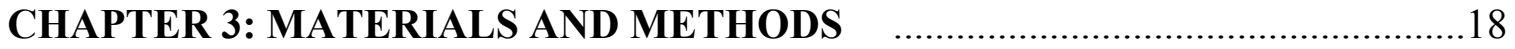

TISSUE PREPARATION AND GENOTYPING ..........................................18

STAINING, CELL CULTURE AND SECTIONING.......................................18

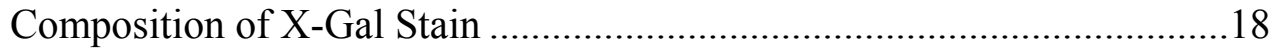

X-Gal Staining Technique ...............................................................19

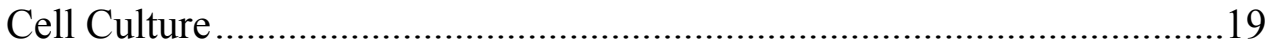

Presence of Neural Crest-Derived Stem/Progenitor Cells in the

Dental Pulp of Postnatal Mice .................................................................19

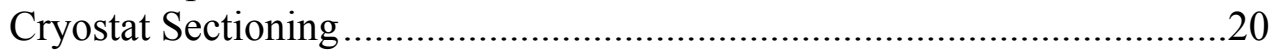


Determination of the Extent of Neural Crest Cell Contribution in the Formation of Craniofacial Tissues in Mice

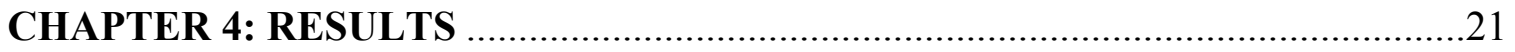

PCR GENOTYPING OF Wnt1-Cre ${ }^{+}$loxP ROSA ${ }^{+}$MICE.....................................21

CONFIRMATION OF CRE-MEDIATED RECOMBINATION ...........................21

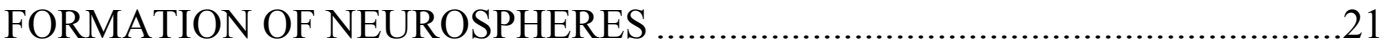

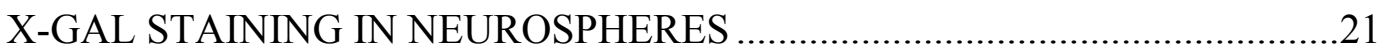

ORIGIN OF DENTAL PULP STEM/PROGENITOR CELLS .............................29

CONTRIBUTION OF NEURAL CREST CELLS TO ALVEOLAR BONE,

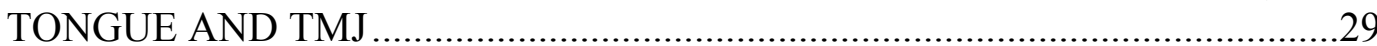

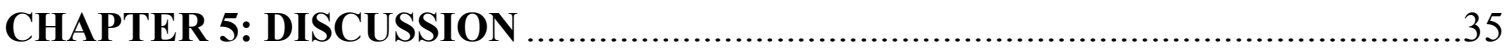

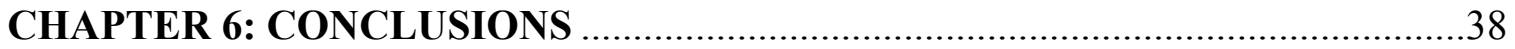

CHAPTER 7: LIMITATIONS AND FUTURE APPLICATIONS ………….............39

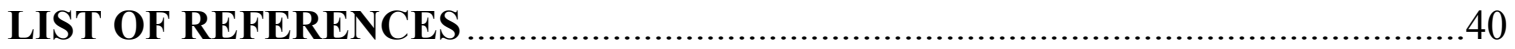

VITA 


\section{LIST OF FIGURES}

Figure 2.1 Cre Recombinase Fate Mapping ......................................................17

Figure 4.1 Comparison of PCR Genotyping …..............................................22

Figure 4.2 Dorsal Root Ganglia and Vibrissae.....................................................23

Figure 4.3 X-Gal Stained Vibrissae at Various Magnifications................................24

Figure 4.4 X-Gal Stained Dorsal Root Ganglia at Various Magnifications................25

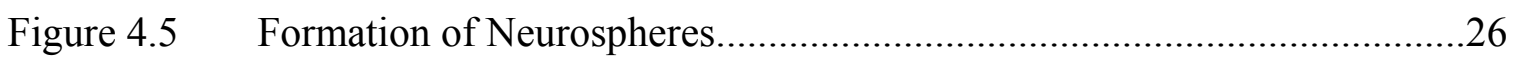

Figure 4.6 X-Gal Staining in Neurospheres ......................................................27

Figure 4.7 Enlarged View of X-Gal Stained Neurospheres .................................28

Figure 4.8 Dental Pulp Cells Stained with X-Gal and Nuclear Fast Red...................30

Figure 4.9 Magnified View of X-Gal Stained Tongue and Surrounding Tissues.......31

Figure 4.10 Magnified View of X-Gal Stained Developing Teeth, Alveolar

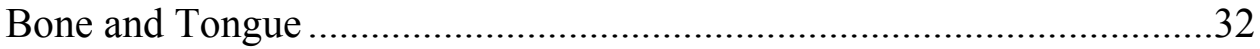

Figure 4.11 Magnified View of X-Gal Stained Tongue and Teeth.............................33

Figure 4.12 Magnified View of X-Gal Stained Trigeminal Ganglion and Surrounding Tissues 


\section{CHAPTER 1: INTRODUCTION AND BACKGROUND}

Stem cell biology is a rapidly advancing arena of basic research, applications of which are potentially crucial to regenerative medicine. In order to develop stem cell based therapeutics, research directed at elucidating the developmental, cellular and molecular mechanisms underlying tissue morphogenesis and related developmental disorders is essential. Craniofacial developmental research requires an understanding of the roles of cell signaling and movements, genetic interactions, transcriptional regulations within time and space and the continuously orchestrated reciprocal tissue-tissue interactions involved in controlling key developmental events. Inherently, the process of mammalian craniofacial development and morphogenesis is complex and clearly reflects evolution-based changes.

Craniofacial tissues have origins from all three germ layers. The neural crest is a unique multipotent stem cell population of embryonic cells, which is restricted to vertebrates (Gans \& Northcutt, 1983; Hall \& Horstädius, 1988). The cranial neural crest (CNC) cell population is derived from the lateral ridges of the neural plate during early embryogenesis. The induction, emigration, proliferation and eventual fate determination of cranial neural crest (CNC) cells during embryogenesis are key events in the process of craniofacial development because $\mathrm{CNC}$ tissue not only gives rise to various face and neck structures, (Le Douarin, 1982) but is also a source of crucial patterning information which drives craniofacial developmental events (Noden, 1988). Nascent neural crest cells delaminate from the developing neural tube, acquire mesenchymal characteristics and migrate to through the embryo to distant sites and proliferate ultimately the $\mathrm{CNC}$ gives rise to various tissue derivatives in the craniofacial skeleton including majority of the head skeleton (Noden, 1988; Couly et al., 1993).

The vertebrate skull, including teeth and pharyngeal skeleton are considered to have a distinct origin, arising from post migratory CNC cells, whereas hard tissues in the rest of the body are derived from mesoderm cells. CNC cells are known to differentiate into a variety of cellular phenotypes, including intramembranous bone, cartilage, muscle, and nerves in the craniofacial region (Creuzet et al., 2005, Noden \& Trainor, 2005) Genetic disorders or environmental stresses can result in differences in patterning of CNC cells and thus alter their fate determination, leading to craniofacial malformations such as facial clefts. The neural crest induction occurs by interaction between cells of the neural plate and adjacent surface ectoderm (Meulemans \& Bronner-Fraser, 2004). Tissue-tissue interaction and concerted signaling is critical to the embryonic induction of neural crest precursor cells.

$\mathrm{CNC}$ cells contributing to the face originate from the caudal forebrain, midbrain, and rostral hindbrain. These then migrate to the ventrolateral aspect of the head, and populate the mesenchyme of the facial primordia or ectomesenchyme such as the frontonasal prominence and branchial arches (Osumi-Yamashita et al., 1994; Köntges \& Lumsden, 1996). Once positioned, these proliferate and differentiate into distinct craniofacial elements (Helms \& Schneider, 2003; Santagati \& Rijli, 2003). 
Many studies have shown evidence that the CNC cells are developmentally plastic, meaning that their fate is not predetermined before they reach their final destination. Instead, they are multipotent progenitor cells, and local signaling from surrounding tissues drives generation of skeletal elements of appropriate shape and size in the craniofacial region. Tissues that provide the instructive signaling for CNC fate specification include the pharyngeal endoderm, the branchial arch ectoderm, and the isthmus organizer at the midbrain-hindbrain boundary (Baker \& Bronner-Fraser, 2001; Couly et al., 2002; Trainor et al., 2002; Le Douarin et al., 2004). Various animal study models have shown that $\mathrm{CNC}$ cells give rise to tissue specific stem/progenitor cells in craniofacial tissues such as the tongue, temporomandibular joint and alveolar processes (Morrison et al., 1999; Bixby et al., 2002; Kruger et al., 2002). Craniofacial abnormalities comprise at least a third of all congenital defects and are largely considered as attributable to defects in formation, proliferation and migration of $\mathrm{CNC}$. Thus, knowledge of the basic biology of the CNC cells, and their ontological derivatives is important to ultimately utilize the properties of this cell population in regenerative medicine applications in the craniofacial perspective such as stem/progenitor cell based dental and craniofacial tissue engineering.

Postnatal mesenchymal stem/progenitor cells (MSC) can be harvested from dental pulp of both deciduous and permanent teeth. Dental pulp thus contains a repository of MSC (Gronthos et al., 2000, 2002, 2003; Miura et al., 2003), known as dental pulp stem/progenitor cells (DPSC) and these have potential regenerative applications (Nosrat et al., 2001; Nosrat et al., 2004). It has been suggested that DPSC are of mesodermal origin. However, the fact that neural crest contributes to the formation of the majority of the cell types in the dental pulp proper (Chai et al., 2000), whereas intrapulpal blood vessels are the source for cells of mesodermal origin (Cho et al., 2003), led to the development of the hypothesis that the dental pulp also contains stem/progenitor cells of CNC origin (Chai et al., 2000; Yu et al., 2007; Stevens et al., 2008).

The formation of alveolar bone is both dependent on and coordinated with tooth development (Jakobsen et al., 1991; Kjaer et al., 1994; Chavez-Lomeli et al., 1996). The alveolar bone development involves $\mathrm{CNC}$ cell-derived mesenchymal cell condensation in order to form the dental sac, followed by osteoid deposition and intramembranous mineralization of the socket around the developing tooth (Chai, 2000; Sodek, 2000 Zhang, 2003). Dental tissue engineering thus necessitates the coordinated development of alveolar bone, which can integrate with and support a bio-engineered tooth (Chai, 2009). Anomalies in CNC patterning or its timing can result in disruption of normal bone and tooth development causing tooth agenesis, tooth malformation or deviations in eruption pattern. Thus, $\mathrm{CNC}$ contributions to alveolar bone development and related events underlying its patterning and fate determination require further study.

Understanding CNC contributions to key craniofacial structures such as the temporomandibular joint (TMJ) and the tongue is crucial to our knowledge of developmental biology in this region. The TMJ is a synovial joint between the mandibular condyle and the mandibular fossa within the temporal bone. It plays a pivotal role in complex jaw movements, which are one of the most complicated movements in 
the body. Embryonic development of TMJ has been the subject of intense academic debate. A more detailed understanding of the TMJ's developmental events and their determinants would clarify the etiology, development and aid in the treatment of TMJ disorders (Tanaka et al., 2008). The tongue is a specialized muscular organ functioning in taste perception, speech and mastication. It develops from neural crest derived pharyngeal arches. Tongue muscle develops uniquely from myogenic precursor cells derived from occipital somites migrating to tongue primordium. Circumferential neural crest cells are considered to arise from posterior rhombencephalon, migrate cranially and contribute to precursors of tongue muscles (Köntges \& Lumsden, 1996).

Avian embryos (chicken and quail) are conventionally used for grafting/transplantation experiments to understand the developmental biology of craniofacial structures. Zebrafish craniofacial developmental studies are more recent, and have resulted in the identification of new cell signaling interactions (Trainor \& Krumlauf, 2000; Yelick \& Schilling, 2002). Likewise, murine models are amenable to genome manipulation, and thus have led to great progress in developmental research, as they combine the advantages of genetics together with in vitro organ culture techniques. The combination of human genome data with the data derived from functional genomic investigations in mouse models, has led to the discovery of morphoregulatory genes that determine craniofacial morphogenesis, using techniques such as human genetic linkage analysis (Thyagarajan et al., 2003; Murray \& Schutte, 2004).

In spite of recent advances, our current knowledge of embryonic CNC development and the molecular mechanisms involved environmental cues that mediate neural crest cell lineage induction, differentiation, and final contribution to various tissues (Shah et al., 1996; LaBonne \& Bronner-Fraser, 1999; Chai et al., 2003; Le Douarin et al., 2004), require further study before the full potential of these cells can be exploited for therapeutic applications.

Thus, the purpose of this project was to determine the contribution of neural crest cells to dental stem/progenitor cells and craniofacial structures (alveolar processes, tongue and temporomandibular joint). The hypotheses tested were that:

- There are two distinct populations of adult stem/progenitor cells in the dental pulp, originating separately from the mesoderm and the neural crest.

- The neural crest cells contribute to the formation and development of the dental pulp, craniofacial structures such as alveolar process, tongue and temporomandibular joint.

The hypotheses were tested by accomplishing the following specific aims:

- Specific Aim 1: Determining the presence of neural crest-derived stem/progenitor cells in the dental pulp of postnatal transgenic mice. 
- Specific Aim 2: Determining the presence of cells of a neural crest cell lineage in dental pulp, alveolar processes, temporomandibular joint and tongue in postnatal transgenic mice. 


\section{CHAPTER 2: REVIEW OF LITERATURE}

\section{THE CRANIAL NEURAL CREST AND ITS ROLE IN CRANIOFACIAL MORPHOGENESIS}

\section{General Aspects and Origin}

Neural crest (NC) cells were first discovered in chick embryos by His et al. in 1868, who determined that the $\mathrm{NC}$ cell population lies between the dorsal ectoderm and neural tube and these cells are the precursors of the cranial and spinal ganglia (His, 1868). Initially this unique tissue was called Zwichenstrang (the intermediate cord), but was later renamed the neural crest by Arthur Milnes Marshall, a term which represents its anatomical origins (Hall, 1999).

The neural crest is unique in that it is restricted to vertebrates, distinct from their chordate ancestors, and, comprises of a distinct population of migratory multipotent embryonic cells arising from the embryonic neural tube (Gans \& Northcutt, 1983; Hall \& Horstädius, 1988). The migration of NC cells occurs after they undergo epithelialmesenchymal transition. The NC cells migrate in streams to different anatomic regions of the developing embryo. These cells then give rise to the formation of various structures such as heart, blood vessels, peripheral nervous system (generating derivatives such as neurons and glia), bone, skeletal muscles, meninges, organs such as ear, eyes, skin, and teeth. They also contribute to connective tissue components of pituitary, lacrymal, salivary, thyroid and parathyroid glands, and thymus (Le Douarin \& Kalcheim, 1999).

In vertebrates, neurogenesis begins with formation of the neural plate, which extends the length of the body axis from head to tail. The neural plate is initially a flat, single-cell-layer-thick, columnar neuroepithelial sheet. Curling and fusion of the two bilateral halves of the neural plate then forms the neural tube, the structure from which the vertebrate central nervous system develops. Neural crest cells are ectodermally derived from the neural tube along almost the entire length of the embryo neuraxis. Rhombomeres are transient and segmented pattern of swellings in embryonic hindbrain (rhomboencephalon), which give rise to NC. At the neural folds and/or the 'neural plate border', a term used to describe the junction between the non-neural ectoderm (presumptive epidermis/surface ectoderm) and the dorsal region of the neural plate, the $\mathrm{NC}$ cells originate.

$\mathrm{NC}$ cells arise from this dorsolateral region of the neural tube (Sadaghiani \& Thiebaud 1987; Hall \& Horstädius, 1988; Le Douarin et al., 1994; Bronner-Fraser, 1995) in the form of two regional populations; the cranial and trunk NC cells. Both trunk and cranial neural crest (CNC) give rise to cells such as melanocytes, neurons, and glia, but $\mathrm{CNC}$ is specialized in that only $\mathrm{CNC}$ cells have the additional ability to form hard tissue like bone and dentin along with cartilage, muscle, and connective tissue derivatives. Hence, $\mathrm{CNC}$ cells are a major contributor to craniofacial skeletogenesis, providing the 
vertebrate skull and associated tissue with developmental origin, as compared to other parts of the body. Trunk neural crest cells contribute to form sensory and autonomic neurons, melanocytes, enteric neurons of the gut, and endocrine cells of the adrenal gland (Anderson, 1997; Groves \& Bronner-Fraser, 1999).

\section{Cranial Neural Crest Cell Induction, Migration and Segregation}

Tissue interactions between neural plate and surface ectoderm are responsible for neural crest cell induction. These interactions are contact mediated and also restricted within planes (Rollhauserter Horst, 1977; Moury \& Jacobson, 1990). Consequent to induction the $\mathrm{NC}$ differentially expresses proteins resulting in epithelial-to-mesenchymal transition (EMT) and NC delamination. Thus NC induction is dependent on two events: firstly, the ectodermal response to a neural inducer from the mesoderm (Albers, 1987; Mancilla \& Mayor, 1996) and secondly, the aforementioned interaction of the neural plate with the non-neural ectoderm (Rollhauserter Horst, 1979; Moury \& Jacobson, 1989, 1990).

The bone morphogenic protein (BMP) mediated signaling gradient is an important feature on which the neural plate surface-ectoderm interactions are dependant. NC induction requires very precise threshold concentration gradient of BMP signaling (Mayor et al., 1995; Morgan \& Sargent 1997), which has been demonstrated in animal models (Liem et al., 1995; Kanzler et al., 2000). The underlying mesoderm contributes to this process by regulation of this BMP gradient due to actions such as BMP inhibitors (Marchant et al., 1998). It is now known that developing somites provide signals for regulation of BMP4 and this is crucial to NC cell delamination (Sela-Donenfeld \& Kalcheim, 2000; Burstyn-Cohen et al., 2004; Bronner-Fraser, 2005; Taneyhill et al., 2006; Shoval et al., 2007). It is likely that BMP acts as a crucial morphogen required for neural crest cell induction.

Other signaling events are also essential to NC induction. Surface ectoderm mediates NC cell inductions by means such as WNT signaling (Garcia-Castro et al., 2002; Lewis et al., 2004). Also, FGF signaling derived from underlying mesoderm has been shown to independently induce neural crest cell formation in frogs (Monsoro-Burq et al., 2003). Thus, WNT and FGF signaling are likely to provide parallel but independent neural crest-inducing pathways (Monsoro-Burq et al., 2005). The interplay of various signaling pathways like BMP, Notch, FGF, and WNT occurring in the neural plate border region are critical for neural crest cell differentiation.

After delamination, NC cells start migrating either ventrally close to the neural tube or dorso-laterally in proximity to the somatic ectoderm (future skin) (Weston, 1963; Keynes \& Stern, 1984; Erickson \& Perris, 1993). The migration of CNC cells occurs in three distinct streams, each arising from one of trigeminal, hyoid, and post otic rhombomeres (Noden, 1983; Le Douarin et al., 1993). This streaming and segregation of $\mathrm{CNC}$ is necessary to the organization and patterning of the craniofacial region. The anatomical location of each rhombomere determines its anteroposterior identity. 
Consequently, this distinct anatomical identity of each subpopulation of CNC influences the developmental assembly of the craniofacial skeleton. This process is tightly genetically regulated and determined by nested expression of a class of homeodomain factors, the Hox genes that are distinct to each rhombomere. Hox gene expression causes NC cells to respond differentially to endoderm cues (Couly et al., 2002; Creuzet et al., 2002). Dix genes are determinants of dosroventral axis, and comprise other cues resultant in NC cell mediated patterning (Simeone et al., 1994).

The first CNC stream (trigeminal crest) arises from the midbrain and rhombomeres 1 and 2 of the hindbrain. It forms neurons of the trigeminal ganglion and the components of the orofacial prominences and mandibular arch - the skeleton of the lower and upper jaw (Lumsden et al., 1991; Schilling \& Kimmel, 1994). The second NC stream, the hyoid, arises mainly from rhombomere 4 of the hindbrain and forms neurons of the proximal facial ganglion along with constituents of the second pharyngeal arch the hyoid skeleton (Lumsden et al., 1991; Schilling \& Kimmel, 1994). The post-otic NC arises from rhombomeres 6 and 7 of the hindbrain and forms the neurons of the proximal and jugular ganglia, and the skeletal components of the posterior pharyngeal arches (Lumsden et al., 1991; Schilling \& Kimmel, 1994). The segregation of the cranial crest into distinct streams is evident as soon as they emerge from the neural tube. In mammals CNC migration begins before neural tube closure and lasts for a protracted interval (Morriss-Kay \& Tucket, 1991).

The exact signaling pathways resulting in CNC cells segregation and migration into the pharyngeal arches in three streams are yet to be elucidated, although it is known that multiple tissues contribute these. It has been shown in avian models that inhibitory influences from rhombomeres 3 and 5, which lack NC cells is responsible for NC cell segregation. In these zones, NC cells are lost by apoptosis by signals such as BMP4 from the neighboring segments (Graham et al., 1993). In mammalian embryos, mechanisms underlying the streaming of CNC migration are yet to be elucidated (Trainor et al., 2002).

Thereby, NC cells stop migrating and subsequently differentiate into a variety of cell types. The cues that result in end of NC migration are yet not known. In the head region, the neural crest is the prime source of skeletal tissue, as NC cells primarily pattern the pharyngeal arches. The pharyngeal endoderm also plays a crucial role in organizing the development of the pharyngeal arches (Piotrowski \& Nusslein-Volhard, 2000).

\section{Multipotency of Neural Crest Cells: Cranial Neural Crest Stem Cells (CNSC)}

Whether postmigratory $\mathrm{NC}$ cells are a pluripotent population or whether their fates are restricted since the commencement of migration or during early migration, has been a subject of debate. NC cells have been considered as stem/progenitor cells, due to their ability to self-renew and differentiate along multiple cell lineages in many in vitro studies (Crane \& Trainor, 2006). But whether these abilities are retained in vivo, and to what extent are issues as of yet unresolved. 
The multipotent ability of NC cells was initially reported by in vitro studies in quail embryos (Sieber-Blum \& Cohen 1980). In cell culture, isolated human embryonic NC-like cells have shown differentiation potential into various cell lineages including; Schwann cells, glial cells, peripheral neurons, melanocytes, pericytes, adipocytes, osteoblasts, and chondroblasts (Lee et al., 2007; Motohashi et al., 2007). Data from avian embryos comprised the first in vivo evidence of multipotency of a trunk NC cell which differentiated into various cell lines including neurons, glia, melanocytes, and adrenomedullary cells (Bronner-Fraser \& Fraser 1988).

In some studies, in vitro evidence from migrating quail $\mathrm{CNC}$ has shown that $\mathrm{CNC}$ gives rise to clones comprised of only one or two distinct cell types (Baroffio et al., 1991). Along side, zebrafish experiments have indicated NC cells to be a heterogeneous population of unipotent cells that are committed to differentiate along specific cell lines before migration (Raible \& Eisen 1994; 1996). Thus, two concepts were purported: 1) migrating CNC cells carry certain preacquired molecular signals such as endogenous $W n t$ signaling (Dorsky et al., 1998). 2) As CNC cells reach their final destination, they are locally regulated by signaling growth and transcription factors such as FGF8 and acquire positional identity at this time (Trumpp et al., 1999). These findings are suggestive of the fact that differences in NC cells multipotency might be either species specific or related to differences in the time span over which NC cell differentiation occurs in different species.

It has been demonstrated by cell labeling studies that a single cell within the dorsal neural tube can produce migrating cells with multipotent abilities, while other similarly labeled cells are retained within the neural tube (Bronner-Fraser \& Fraser, 1988). This implies that pre migratory NC cells are pluripotent or stem/progenitor cells, and as NC cell migration proceeds, the differentiation potential of these cells becomes rapidly more restricted. Together, these findings suggest that post-migratory NC actually contain largely progenitor cells, composed of unipotent and multipotent cells with a restricted differential potential, along with fewer numbers of pluripotent neural crest stem/progenitor cells (NCSC). Within the post migratory NC population, which can be identified in late gestation or postnatally, only a small proportion of NCSC are retained (Crane \& Trainor, 2006).

Isolation of a NCSC enriched cell population requires identification of markers specific to a pluripotent cell subpopulation. The first in vitro evidence of isolation of an enriched population of NCSCs possessing multipotential lineage was reported from mouse trunk neural tubes, by fluorescent activated cell sorting using an antibody to the low-affinity nerve growth factor receptor (p75) which was suggested as a marker for NCSC identification (Stemple \& Anderson 1992). More recently, it was evidenced that a subpopulation of cells in the dorsomedial region of the neural tube expressing the receptor tyrosine kinase, Kit, but negative for p75 demonstrated melanocytic differentiation potential (Wilson et al., 2004). These findings constitute the basis for a hypothesis that two distinct multipotent and unipotent neural crest progenitor cell populations exist in the neural tube, determined by $\mathrm{NC}$ cell precursor segregation. Recent data indicates human NCSC to have a unique molecular profile, with similarities to that 
of pluripotent embryonic stem/progenitor cells and a subset of transcriptomes, which can aid in specific recognition of NCSC (Thomas et al., 2008).

Over the past few years NCSCs have been identified in various tissues and their multipotent ability demonstrated, such as dermal NCSC within adult mammalian hair follicle, and the skin of the face (Sieber-Blum et al., 2004). NCSC were identified by using of a neural crest specific Wntl promoter driving lacZ expression. Sphere forming ability from single cell is indicative of multipotential property (Potten \& Loeffler, 1990; Stemple \& Andersen, 1992). In this context, adult cardiac NCSCs have been isolated in the form of cardiospheres (Tomita et al., 2005).

\section{Cranial Neural Crest Stem/Progenitor Cells (CNSC) in Dental Tissues}

Evidence that CNSC can be harvested from different dental tissues has been demonstrated by many studies over recent years. The first direct evidence that CNC cells contribute to the formation of dental tissue including dental mesenchyme, dental papilla, odontoblasts, dentine matrix, pulp, cementum, periodontal ligaments, was obtained from a two component genetic system (Chai et al., 2000). Mesenchymal stem/progenitor cells from adult human dental pulp demonstrate in vitro neurogenic and adipogenic differentiation potential, suggestive of their neural crest ontogeny (Gronthos et al., 2002) with label retaining and neurosphere forming abilities (Sasaki et al., 2008, Stevens et al., 2008). It has been suggested that the dental pulp comprises of two ontogenically distinct progenitor cell populations, with one demonstrating embryonic neural crest cell markers (Waddington et al., 2009), implying that progenitor cell populations in the dental pulp may be either neural crest or mesodermal in origin. Recently, stem/progenitor cells from human dental pulp were shown to differentiate in vivo into functionally active neurons and direct in vivo axon guidance, by inducing host neuroplasticty, suggesting a potential use in central nervous system regenerative applications in future (Arthur et al., 2009). Stem/progenitor cells from the pulp of human exfoliated deciduous teeth form sphere-like clusters when cultured in a neurogenic medium, along with in vivo neurogenic potential (Miura et al., 2003). They exhibit neural and glial markers and the phenomenon of neurosphere formation, indicating a high proliferative capacity analogous to CNSC (Miura et al., 2003). Similarly, stem/progenitor cells from apical papilla or the soft tissue around apices of developing permanent teeth also show several neural markers (Abe et al., 2007; Sonoyama et al., 2008;). In a comparative study stem/progenitor cells from exfoliated deciduous teeth showed greater neuronal differential potential as compared to cells from dental follicle (Morsczeck, et al., 2009) suggesting that there may exist inherent differences in regenerative potential of CNSC from different dental niches.

\section{Cranial Neural Crest Contributions to Craniofacial Development}

In vertebrates, the cranial vault and pharyngeal skeleton has a unique developmental origin, not found in non-vertebrates, as it develops from mesenchymal cells populations which are NC-derived along with the head mesoderm. These 
developmental events rely heavily upon epithelial-mesenchymal interactions, which serve as cues. The plasticity of CNC cells can be considered as a time dependant variable due to their ability to alter their Hox expression following local signaling patterns (Schilling et al., 2001). The knowledge of molecular controls regulating early development of neural crest cells within the branchial arches and exact contributions to various craniofacial tissues is as of yet limited and merits research.

The extent to which NC contributes to calvarial bones has been the subject of debate with different studies implying differing levels of NC contribution to skull development. A few studies using quail chick chimeras suggest that a boundary exists within the frontal bone delineating neural crest-non-neural crest derived tissue (Evans \& Noden, 2006). Some studies suggest that the entire chick cranial vault is of neural crest origin (Couly et al., 1993). In the mouse, the interface between the frontal and parietal bones, the coronal suture, has been shown as a boundary between neural crest and mesoderm (Merrill et al., 2006). These facts are likely to suggest that genera related differences exist in terms of the NC contribution to craniofacial development (Gross \& Hanken, 2005). Knowledge of the differential contribution of CNC and non-CNC tissue has implications, as these boundary areas are known to be key signaling areas and consequently affect control and direction of growth. Among different vertebrates, $\mathrm{CNC}$ derived mineralized tissue patterning is modified at the embryological level resulting in significant interspecies morphological differences.

Interaction between the oral ectoderm and the CNC-derived mesenchyme within the first branchial arch are imperative to mandibular development. In the mouse embryo, the first branchial arch (mandibular arch) becomes apparent at E8.0-E8.5 (6-8 somites) as small swellings on lateral aspects of the developing head. CNC cells originating from midbrain, rhombomeres $\mathrm{r} 1$ and $\mathrm{r} 2$ migrate into and proliferate within the mandibular arch (Lumsden et al., 1991). These CNC-derived cells localize subjacent to the overlying epithelium (Chai et al., 2000). Area specific expression of signaling molecular profiles, such as BMP, TGF- $\beta$, and FGF, occurs in the oral ectoderm (Chai et al., 1994, 1997; Ito et al., 2002; Liu et al., 2005). These molecules selectively regulate genetic expression within CNC-derived mesenchyme of the homeobox containing genes (such as Dlx, Lhx, and Gsc). This mechanism is responsible for directing tissue polarity and the patterning of the first branchial arch.

Tooth development begins with formation of dental lamina at E12. The condensed mesenchyme or dental sac lying subjacent to dental lamina in early bud stage at E13.5 is enriched with $\mathrm{CNC}$ derived mesenchymal cells. As tooth germ progresses from the bud to the cap stage, CNC-derived mesenchymal cells become concentrated at the interface with the enamel organ epithelium, while the periphery of the dental sac is populated with both $\mathrm{CNC}$ and an increasing number of non-CNC-derived cells. Molecular signaling from within the enamel organ epithelium and the CNC-derived dental mesenchyme is reciprocal and crucially determines tooth morphogenesis (Chai et al., 2000; Jernvall \& Thesleff, 2000). Role of CNC in tooth morphogenesis has been directly evidenced by transgenic mouse models (Chai et al., 2000) and implied by others (Sharpe, 1995; Tucker et al., 1998). 
Similarly, CNC cells are similarly critical for palatogenesis and palatal fusion. CNC cells contribute greatly to the palatal mesenchyme (Chai et al., 2000; Ito et al., 2003). These CNC cells provide the basis for genetic heterogeneity along the anteriorposterior and medial-lateral axes of the developing palate. The interplay between reciprocal signals between palatal epithelium and $\mathrm{CNC}$ derived mesenchyme determine the patterning along A-P axis and events of palatogenesis by serving as regulatory mechanisms for this genetic heterogeneity (Zhang et al., 2002; Rice et al., 2004) and directing the fusion of the anterior vs. posterior region of the palate (Hilliard et al., 2005).

CNC contributions to the tongue, a predominantly muscular organ are derived from all branchial arch levels, as shown in an avian model (Kontges \& Lumdsen, 1996). In this regard, the tongue can be considered a uniform and composite organ, as its anatomical boundaries do not coincide developmentally with $\mathrm{CNC}$ cell population boundaries, unlike as in the cranial skeleton. However, individual CNC populations do result in delimitation of insertion sites of hypoglossal and branchial muscles on the adjacent skeletal structures.

\section{STUDY MODELS FOR CRANIAL NEURAL CREST CELL BIOLOGY}

Various study modalities have been used over the last few decades to study the characteristics and fate of CNC cells in craniofacial development. While avian study models are used chiefly for grafting and transplantation studies, mouse models are amenable to functional genomic investigations and genetically mutated models serve to highlight genetic mechanisms underlying craniofacial development. Zebrafish craniofacial developmental studies have emerged recently and mutant screens have led to the identification of new cell signaling interactions (Trainor \& Krumlauf, 2000).

\section{Classical Ablation Experiments}

The earliest data regarding NC was derived from classical ablation experiments, where a thin slice of embryonic neural fold tissue was resected, in order to evaluate the resultant developmental restriction, however this model is deficient due to inherent NC self renewal (Stemple \& Andersen, 1992).

\section{Explantation Studies}

These entail specific in vitro culture conditions, which allow neural crest cells to grow and express their development potentialities when plated as single cells in defined media (Sieber-Blum \& Cohen, 1980). These studies primarily validated differing pluripotency of NC lineage cells, suggesting that NC plasticity is in part likely to be determined by local territorial signaling. 


\section{Cell Marking Techniques}

This technique involves labeling the DNA of migrating NC cells with tritiated thymidine, a radioactive label (Wetson, 1963). Migration of cells labeled with tritiated thymidine can be followed by autoradiography. However, as label dilution occurs over successive cell multiplications, it limits the progeny that can be traced and the results may be confounded by release from non-vital cells. Later, the advent of a non-toxic fluorescent marker, lysinated rhodamine dextron (LRD), has been used to an advantage in clonal analysis of NC cells (Larsen, 1997).

\section{Cell Lineage Studies Using Retroviruses}

In mammals, intrauterine injection of fluorescent lineage tracers to tag developing embryonic NC cells is not possible. Thus, lineage analyses have relied on the injection of progenitor cells with replication defective retroviral DNA (Sanes et al., 1986). Viral structural genes have been substituted by bacterial ß-galactosidase gene $l a c Z$, and used for NC lineage tracing effectively, as these cells can easily be distinguished both in whole mount preparation and in histological sections.

\section{Transgenic Techniques}

Recombinant DNA techniques enable the insertion of a bacterial transgene into the mouse genome, and this technique has been instrumental in NC lineage studies. As an example; the $l a c Z$ gene inserted into the transgene in a position that puts it under the control of the same regulatory DNA region that controls the expression of the gene for a neurofilament protein called peripherin. As, peripherin is normally expressed in a number of tissues of $\mathrm{NC}$ origin, lac $Z$ gene in these transgenic mice should be activated in all cells that express the endogenous peripherin gene, with the result that all peripherin-producing tissue would stain blue, implying an NC lineage (Larsen, 1997).

\section{Molecular Markers for Neural Crest Lineage}

One of the limitations of earlier used avian models was the prospective labeling of CNSC, as these may change characteristics in culture. Lately, a number of markers have been identified that label migratory NC cells. These include antibodies or probes to the receptor tyrosine kinase-Ret (Pachnis, 1993), low affinity neurotrophin receptor, P 75 NTR (Baetge \& Gershon, 1990), 5-Ht2 B receptor (Florica-Howells et al., 1998), transcription factors MASH1 (Lo et al.. 1991,1997) and Sox10 (Herbaerth et al.. 1998), LNGFR (low-affinity nerve-growth-factor receptor) amongst others (Zhang et al., 2006). 


\section{Avian Study Models}

Avian study models have been primarily used for grafting and transplantation studies. Much of the earlier knowledge has been obtained from avian animal models, chiefly due to ease of avian embryo accessibility.

\section{Quail-Chick Chimeras}

The development of quail-chick chimera system was a landmark in this regard. Quail donor and chick host cells can easily be distinguished by DNA staining or electron microscopy, facilitating NC cell fate mapping (Clarke \& Tickle 1999). Le Douarin (1973) pioneered the use of non-chicken avians for the study of craniofacial development and characterization of neural crest cells. This approach has been systematically applied to the entire neuraxis to establish its fate map.

\section{Quail-Duck Chimeras}

The quail-duck chimeric transplantation comprises a more recent avian model for analysis of NC contributions during craniofacial development is system (Schneider \& Helms, 2003). The differences in beak morphology and embryo maturation times enable assaying the contribution of donor NC-derived ectomesenchyme to pattern the host craniofacial zone. This model has been used to investigate the role of BMPs, especially BMP4 signaling in craniofacial patterning (Merrill et al., 2008).

\section{Mouse-Chick Chimeras}

The combination of mouse and chick models in NC-transplantation experiments has been recently used for investigating the role of $\mathrm{CNC}$ mesenchyme in tooth development, which is restricted to mice (Lwigale \& Schneider, 2008), indicating that neural-crest-derived mesenchyme possesses odontogenic potential to initiate tooth formation. By grafting embryonic mouse $\mathrm{CNC}$ cells into stage-equivalent chick, (Mitsiadis et al., 2003, 2006) demonstrated the successful incorporation of mouse neural crest cells into beak mesenchyme and these mouse-chick chimeras showed ingrowths of oral epithelium with tooth bud and cap configurations (Mitsiadis et al., 2003, 2006).

However, one of the major limitations of avian systems has been the inability to generate transgenic animals. Several factors have hampered stable genetic modification of the chicken genome (Sang, 2006). These include, eggs being difficult to manipulate, due to the abundant yolk and size and also, the relatively advanced stage of development by the time an egg is laid. Recently isolated and cultured primordial germ cells were genetically modified by the incorporation of $\beta$-actin-eGFP, which is a step towards generation of transgenic avian study models (van de Lavoir et al.. 2006). 


\section{Mouse Models and the Cre/lox System}

Mouse models offer the advantages of facilitating both genome manipulation and in vitro organ culture. The mouse shares physiological, anatomical and genomic similarities with humans. Alteration of the mouse genome by conventional transgenic and gene-targeted approaches has greatly facilitated studies of gene function.

Chromosomal engineering techniques need to be specific both for generation of viable embryos, and tissue phenotype specificity as an outcome of genetic modification, so as to enable evaluation of functional effects of a genetic modification. The Cre/lox $P$ site-specific recombination system is one such chromosomal engineering technique suitable for generating viable tissue-specific gene knockout mouse model, and can be used to model chromosomal rearrangements in genetic diseases to and enable the genetic delineation of causes (Sauer, 1987).

\section{CRE RECOMBINASE FATE MAPPING}

The Cre/loxP recombination is the gold standard for generation of conditional knockout animals wherein a specific gene can be knocked out in a tissue, via in vivo gene regulation. The Cre/loxP method, which is generally applied to mice genome, (Sauer, 1998) requires two different genetically engineered mouse lines to achieve a tissuespecific gene deletion, by targeting a specific DNA sequence and splicing it with the help of enzyme Cre recombinase. The Cre protein is a site-specific DNA recombinase that can catalyze the recombination of DNA between specific sites known as loxP sequences, which contain specific binding sites for Cre that surround a directional core sequence where recombination can occur (Sauer, 1987; 1998).

The system requires separate generation of transgenic Cre- and loxP-containing strains of mice that are then crossed to generate offspring with the tissue-specific gene knockout. One mouse strain contains a targeted gene flanked by two-loxP sites ("floxed gene"). The second mouse strain is a transgenic mouse line expressing Cre recombinase that is under the control of a promoter that is specific for a particular cell or tissue type, so the strain expresses Cre recombinase in a specific tissue or cell type or expressing it in a developmentally regulated way. Some offspring generated by crossing these strains will inherit and express both the floxed gene and the Cre-expressing transgene (Sauer, 1998; Kos, 2004).

\section{LoxP Site}

A loxP (locus of crossover P1) is a site on the Bacteriophage P1, comprising of a 34-base pair (bp) DNA sequence that is composed of an 8-bp core (which determines directionality) flanked on either side by $13 \mathrm{bp}$ of palindromic (complementary) sequences. Many such loxP sites can be introduced into the mouse genome by 
bacteriophage-targeted mutagenesis within embryonic stem/progenitor cell lines. The genetic sequences flanked by loxP sites are known as "floxed." The orientation of the paired loxP sites determines if the DNA segment between them will be either excised or inverted by Cre recombination (Sauer, 1987; 1998; Kos, 2004).

\section{Cre Recombinase}

Cre (creates recombination) is a $38-\mathrm{kDa}$-cyclization recombination recombinase enzyme. It consists of 4 subunits and two domains: a larger carboxyl (C-terminal) domain, and smaller amino (N-terminal) domain. It catalyzes recombination between two specific DNA repeats. As Cre recombinase is not naturally expressed in mammalian tissues, it is encoded by the bacteriophage $\mathrm{P} 1$ and requires a transgenic mouse lineage to be created. Depending upon use of specific promoter gene sequences, Cre expression can be targeted to all tissues (knockout) or just a specific tissue or cell type (conditional gene knockout).

Cre recognizes the specific 34-bp nucleotide sequence in a loxP site, functioning by a transient covalent linkage to bring the two-loxP sites together and mediates sitespecific recombination. If two direct lox $P$ repeats are in the same orientation, Cre excises the intervening DNA segment, resulting in a single remaining loxP site. On the contrary, if two-loxP repeats are inverted the intervening DNA segment undergoes inversion and the two-loxP sites remain. Thus using Cre recombinase is a straightforward manner for precise DNA rearrangements and genetic switches to be efficiently generated.

\section{Cre-Expressing Mouse}

The basic method (Kos, 2004) for the creation and production of transgenic tissue specific knockout mice, using Cre recombinase involves the following three steps:

1. Isolation and cloning of the Cre recombinase gene to create a transgenic DNA construct comprising of the Cre gene linked to the end of a specific promoter gene sequence that has been selected so as to target a tissuespecific expression pattern.

2. Transfer of this transgenic DNA construct into the pronucleus of a one-cell mouse embryo, using a viral vector or microinjection.

3. Implantation of the microinjected embryos into the oviduct of pseudopregnant mouse (Kos, 2004).

Various studies have implicated the role of molecules of WNT family in signaling involved in NC formation. Wntl gene expression is crucially linked with NC patterning during embryogenesis. Outside of the midbrain and the dorsal neural tube, Wnt 1 was only expressed in neural crest cells (Parr et al., 1993; Danielian et al., 1997; Ikeya et al., 
1997). Thus, Wnt 1 specific promoters as drivers of the Cre-mediated activity serve to tag Wnt 1 expressing cells. Such cells express after Cre-mediated recombination, and will demonstrate homogeneous $\beta$-galactosidase expression observable by X-gal staining. Cre transgenic mice mated with conditional reporter mice (loxP ROSA mice) (Figure 2.1A), in which lac $Z$ is expressed under the control of a ubiquitous promoter after a floxed stop codon is removed by Cre-mediated recombination, (Figure 2.1B), results in X-gal staining specifically in neural crest derived tissues in $\mathrm{Wntl}_{-\mathrm{Cre}}^{+}$loxP ROSA ${ }^{+}$mice. Thus, while $\mathrm{X}$-gal staining is not expressed in wild or $\mathrm{Cre}^{-}$loxP $\mathrm{ROSA}^{+}$mice, it is expressed in all cells derived from Cre-expressing cells in the $\mathrm{Cre}^{+} \operatorname{lox} P \mathrm{ROSA}^{+}$mice, (Figure 2.1C) implying their $\mathrm{NC}$ origins consequent to $\mathrm{Wntl}$ expression. 


\section{A. Mating scheme}

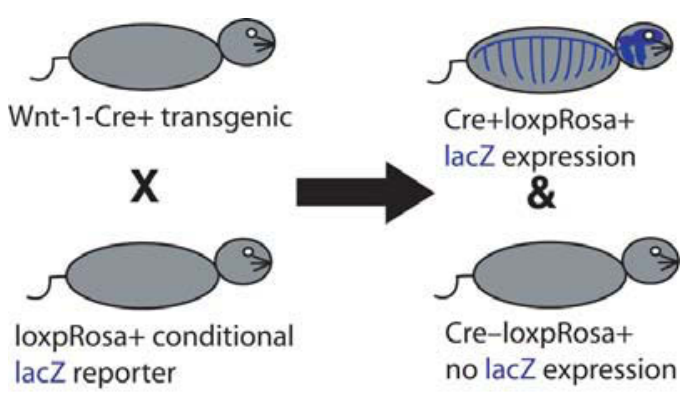

\section{B. Cre-mediated recombination}

\section{Promoter loxp stop loxp, lacz}

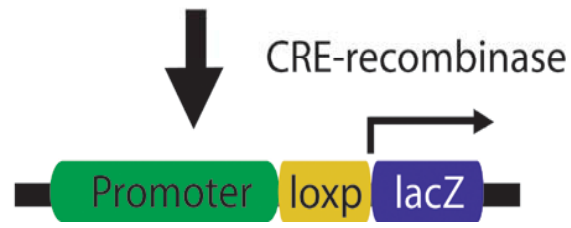

\section{Animals used in the Study}

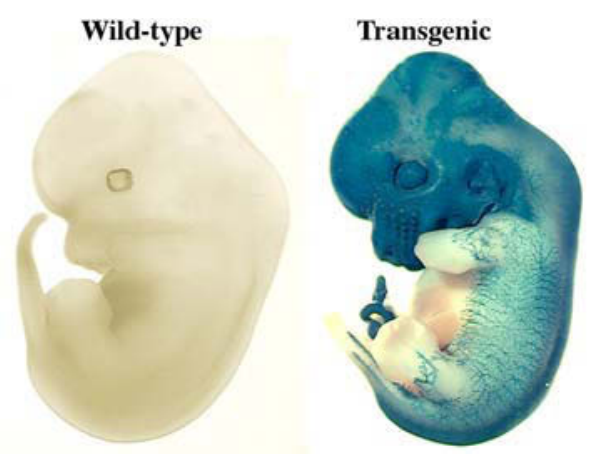

\section{Figure 2.1: Cre Recombinase Fate Mapping.}

Figure 2.1C provided by Dr. Sean Morrison, University of Michigan. Modified, with permission. Joseph NM, Mukouyama, Mosher, et al. Neural crest stem cells undergo multilineage differentiation in developing peripheral nerves to generate endoneurial fibroblasts in addition to Schwann cells. Development 2004; 131: 5599-5612. 


\section{CHAPTER 3: MATERIALS AND METHODS}

\section{TISSUE PREPARATION AND GENOTYPING}

The animals were maintained on a light-dark cycle with light from 0600 hours to 1800 hours. Tissue samples were obtained under approved guidelines set by the Institutional Animal Care and Use Committee (IACUC). Tissue specimens were harvested from the embryos at different embryonic (E13, E16 and E18) and postnatal ages (P3, P7 and P14). The following tissue specimens were obtained: dental pulp, tail, spinal cord, vibrissae and sagital section of the head comprising of maxilla, mandible, temporomandibular joint and tongue. Dental pulps were analyzed by cell culture, tail biopsies by genotyping and the remaining tissue fixed with $0.2 \%$ glutaraldehyde in phosphate-buffered saline and stored in $10 \%$ sucrose solution in a freezer at $-40^{\circ} \mathrm{C}$.

Wnt1-Cre and lacZ reporter mice were crossbred and the offsprings were genotyped. PCR genotyping was performed with Cre- and lacZ-specific primers (Cre: AGCTACACCAGAGACGG and AGATGTTCGCGATTATC, lacZ:

GCTGGGATCCGCCATTGTCAGACATG and

GCTGGAATTCCGCCGATACTGAC) on genomic DNA obtained from tail biopsies.

\section{STAINING, CELL CULTURE AND SECTIONING}

\section{Composition of X-Gal Stain}

The X-gal stain (Invitrogen) used in this experiment was prepared by the combining the following reagents in the proportion listed in the underlying table (Table 3.1) for every $5 \mathrm{ml}$ of the stain.

Table 3.1: Composition of X-Gal Stain.

\begin{tabular}{ccc}
\hline No. & Component & Amount \\
\hline 1. & K3 (Potassium ferricyanide trihydrate) & $250 \mu 1$ \\
2. & K4 (Potassium ferricyanide crystalline) & $250 \mu 1$ \\
3. & NP-40 & $10 \mu 1$ \\
4. & Sodium deoxycholate & $10 \mu 1$ \\
5. & X-Gal (Invitriogen) & $5 \mu 1$ \\
6. & PBS (Phosphate buffered saline) & $4.35 \mathrm{ml}$ \\
\hline
\end{tabular}




\section{X-Gal Staining Technique}

The air-dried slides were placed in $0.2 \%$ glutaraldehyde solution for 30 minutes and then rinsed with PBS solution three times for 10 minutes each. They were allowed to dry again at room temperature, stained with X-gal stain and incubated at $37{ }^{\circ} \mathrm{C}$ for 48 hours. The stain was replaced after 24 hours. In order to stop the reaction after 48 hours the slides were washed with PBS. The stained slides were dehydrated through alcohol and covered with cover slips.

\section{Cell Culture}

Dental pulps were dissected and cultured in 6- and 12-well cell culture plates, as described previously (Nosrat et al., 2001; Nosrat et al., 2004). Cells were subcultured at confluency and medium was changed to Neurobasal-A (Invitrogen), B27 supplement (Invitrogen), penicillin and streptomycin, Fungizone, $20 \mathrm{ng} / \mathrm{ml}$ epidermal growth factor (EGF, R\&D Systems), and 40ng/ml basic fibroblast growth factor (FGF, R\&D Systems). In order to examine the self-renewal capability of dental

pulp stem/progenitor cells, individual neurospheres were mechanically dissociated and single cells grown in the same medium to analyze formation of new neurospheres. Multilineage capability of DPSC was analyzed by either mechanically dissociating individual neurospheres or plating whole neurospheres onto new 12-well plates or glass chamber slides (coated with poly-D-lysine and Laminin), under differentiation conditions (omitting growth factors, addition of 1-10\% serum). Differentiated DPSC were analyzed immunohistochemically using different antibodies. Neurospheres were also stained with X-gal to examine if they were X-gal positive (indicating a neural crest origin). Co-expression of X-gal with these markers would indicate that these cells have originated from the neural crest. Partial co-expression would indicate two different origins for DPSC, while no co-expression would indicate that only non-neural crest mesodermal cells are the origin of DPSC.

\section{Presence of Neural Crest-Derived Stem/Progenitor Cells in the Dental Pulp of Postnatal Mice}

The presence of neural crest-derived DPSC in postnatal mice (ranging from three days to three weeks) was determined using Cre-recombinase fate mapping and cell culture techniques. Wnt1-Cre transgenic mice were mated with loxP ROSA mice in which $l a c Z$ was expressed after a floxed stop codon is removed by Cre-mediated recombination. Outside of the midbrain and the dorsal neural tube, Wntl is only expressed in neural crest cells (Parr et al., 1993; Danielian et al., 1997; Ikeya et al., 1997). Wnt1-Cre ${ }^{+}$loxP ROSA ${ }^{+}$mice would therefore exhibit $\beta$-galactosidase (X-gal) staining specifically in neural crest-derived cells and tissues. Dental pulps were dissected, pooled, and cultured in a neurosphere-inducing medium and evaluated for self-renewal, clonogenic capacity and the ability to differentiate into neural crest derivatives such as neurons, glia and smooth muscle. LacZ expression would indicate 
that such cells have originated from the neural crest. Partial expression would indicate two different origins for DPSC, while no expression would indicate that only nonneural crest; mesodermal cells are the origin of DPSC.

\section{Cryostat Sectioning}

All embryonic and postnatal mice tissues were frozen sectioned and stained according to the standard protocol as follows. Tissues were rinsed with PBS for 10 minutes, embedded in Tissue-Tek O.C.T. (Optimal Cutting Temperature) Compound and frozen into blocks on dry ice. The specimens were sectioned at $16 \mu \mathrm{m}$ thickness using a cryostat and were mounted on gelatin-coated slides. The slides were allowed to dry in the air for 30 minutes prior to staining.

\section{Determination of the Extent of Neural Crest Cell Contribution in the Formation of Craniofacial Tissues in Mice}

As a first step to accomplish this aim the genotypes of animals were determined by polymerase chain reaction (PCR) on tail biopsies of the animals. The Wnt1$\mathrm{Cre}^{+}$loxP ROSA $\mathrm{R}^{+}$positive and negative animals served as experimental and control population for the study respectively. The neural crest derived tissues such as spinal cord and the DRG (dorsal root ganglia) in these animals were examined by histometric analysis to exhibit $\beta$-galactosidase (X-gal) staining. Similar staining of vibrissae and hair follicles was used to distinguish positive and negative animals. The tissues from embryonic (E13, 16 and 18) and postnatal ages (3,7 and 14 days) were processed and sectioned. The extent of neural crest contribution was assessed in the alveolar processes, tongue and temporomandibular joints of mice by using the X-gal staining technique. 


\section{CHAPTER 4: RESULTS}

\section{PCR GENOTYPING OF Wnt1-Cre $e^{+}$loxP ROSA ${ }^{+}$MICE}

Expression of Cre recombinase in the mice was determined by PCR genotyping of tail biopsies. Based on previous studies it is known that only $5-10 \%$ of the mice will be doubly transgenic (that express both Wnt1-Cre and flox stop lacZ), therefore, in addition to PCR screening X-gal staining of spinal cord and vibrissae was used to confirm the recombination. Figure 4.1 shows the results of PCR genotyping in transgenic and wild type mice indicating the presence of both genes in the samples numbered 725 and 730 exhibited by the presence of a dark band in the genotyping results.

\section{CONFIRMATION OF CRE-MEDIATED RECOMBINATION}

$\mathrm{X}$-gal staining was used to verify that Cre-mediated recombination of the floxed stop lac $Z$ locus in the neural crest derived tissues such as dorsal root ganglia and the dermal papillae of vibrissae. Presence of Cre-mediated recombination is indicated by the presence of blue cells in the dorsal root ganglia in the spinal cord and dermal papillae of vibrissae of transgenic ( $\mathrm{tg}$ ) mice, and absence of X-gal staining in wild type (wt) mice as shown in Figure 4.2. X-gal stained vibrissae and dorsal root ganglia of transgenic mice were observed at various magnifications (Figures 4.3 and 4.4).

\section{FORMATION OF NEUROSPHERES}

Dental pulp cells were cultured under neurosphere forming conditions (Neurobasal A, B-27, EGF, bFGF). Dental pulp cells from both wild-type and transgenic Wnt1-Cre ${ }^{+}$loxP $\mathrm{ROSA}^{+}$mice formed neurospheres in culture, as seen in Figure 4.5.

\section{X-GAL STAINING IN NEUROSPHERES}

Preliminary results clearly demonstrated that X-gal stained neurospheres as well as negative neurospheres were obtained from $W n t 1-C r e^{+} l o x P$ ROSA $^{+}$(Figures 4.6 and 4.7). X-gal stained neurospheres express lacZ, indicating that such cells come from neural crest. These results were highly reproducible and doubly transgenic mice (Wnt 1 $\mathrm{Cre}^{+}$loxP $\mathrm{ROSA}^{+}$) could also be generated successfully. 

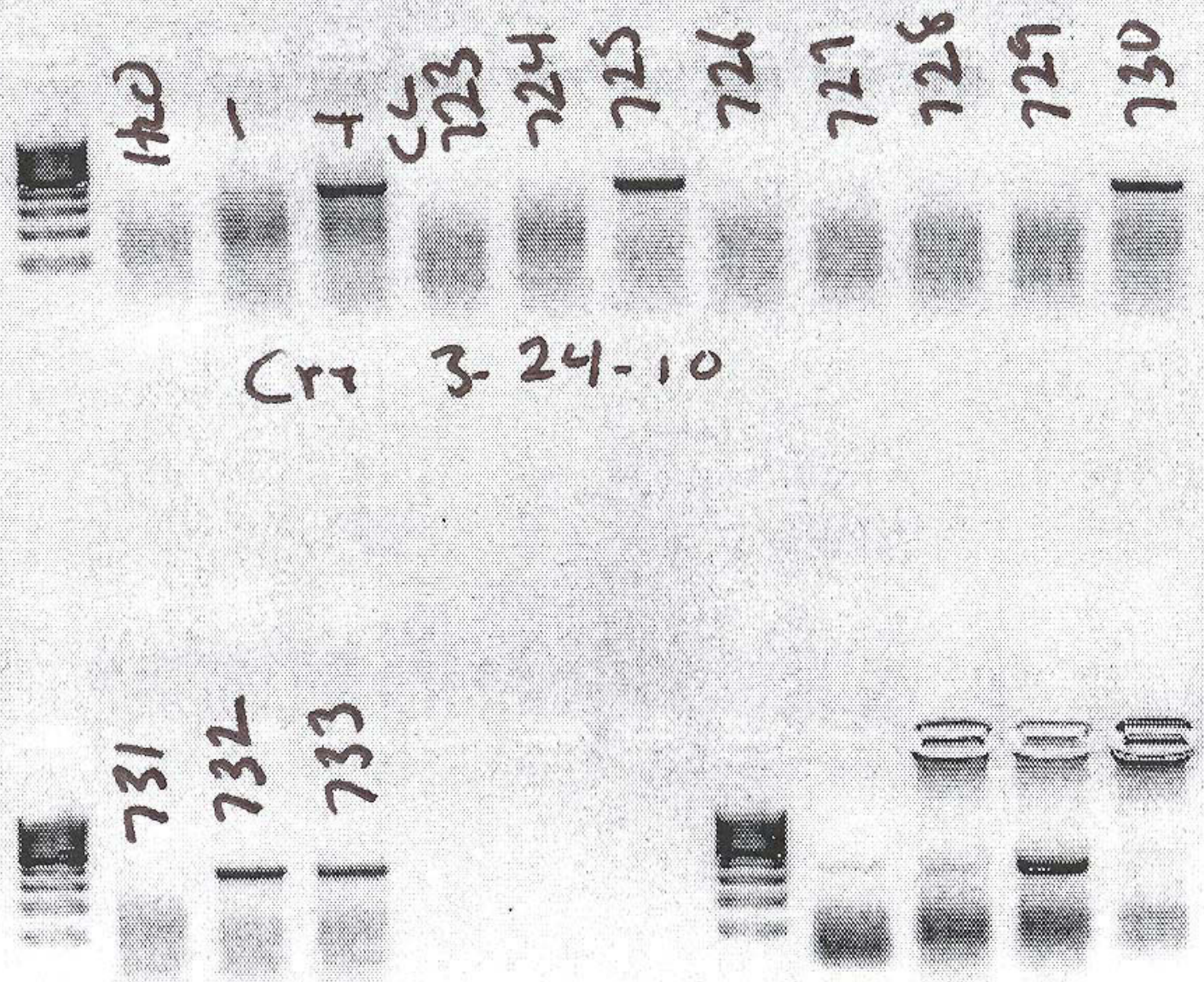

Figure 4.1: Comparison of PCR Genotyping.

This figure shows a comparision of PCR genotyping between $\mathrm{Wnt}_{-} \mathrm{Cre}^{+} l o x P \mathrm{ROSA}^{+}$ and $l a c Z$ reporter mice. 

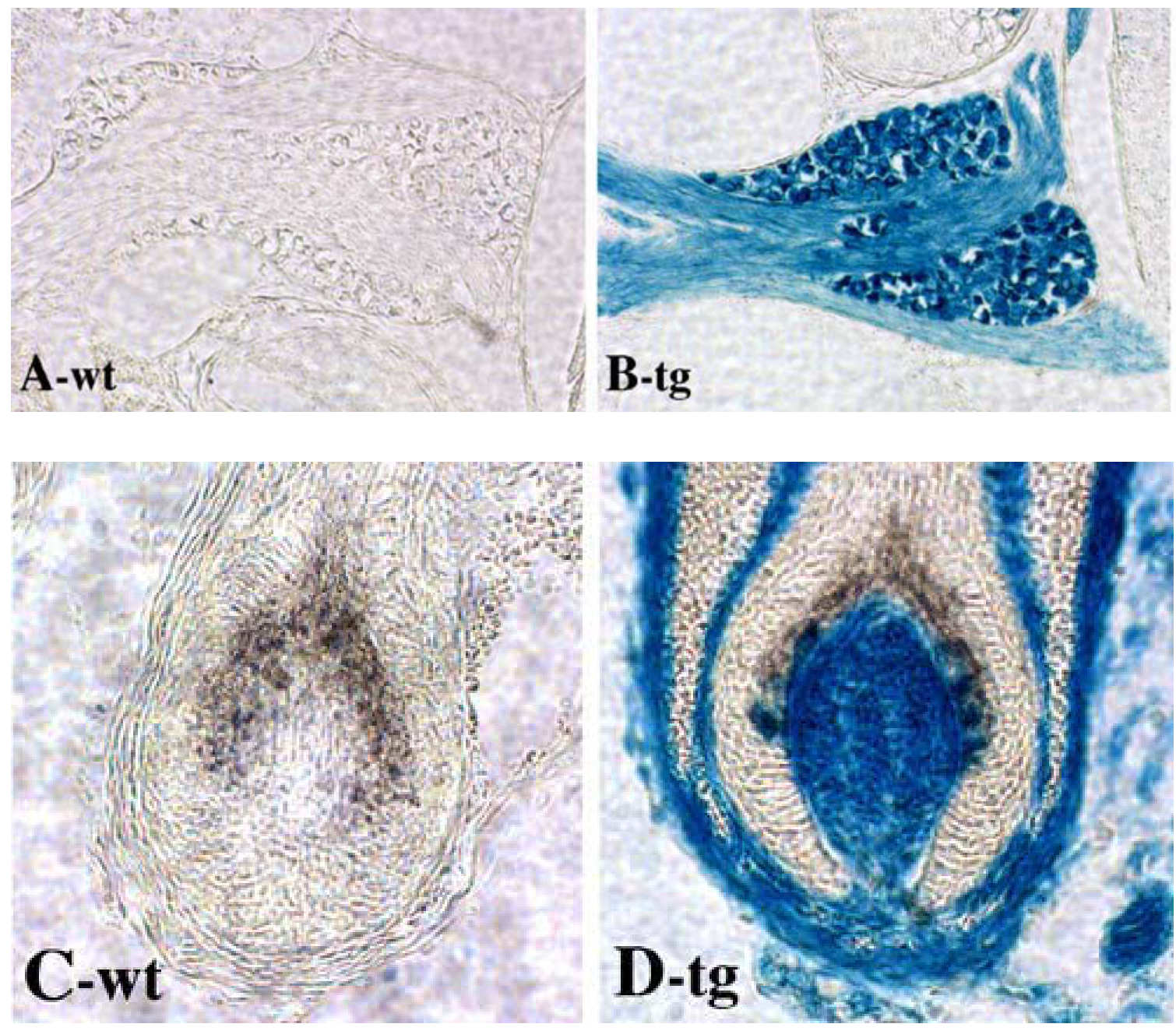

Figure 4.2: Dorsal Root Ganglia and Vibrissae.

Dorsal root ganglia (A-B) in spinal cord and vibrissae (C-D) in dermal papillae from wild-type (wt) and transgenic mice (tg) were stained by X-gal staining technique and visualized under microscope. 

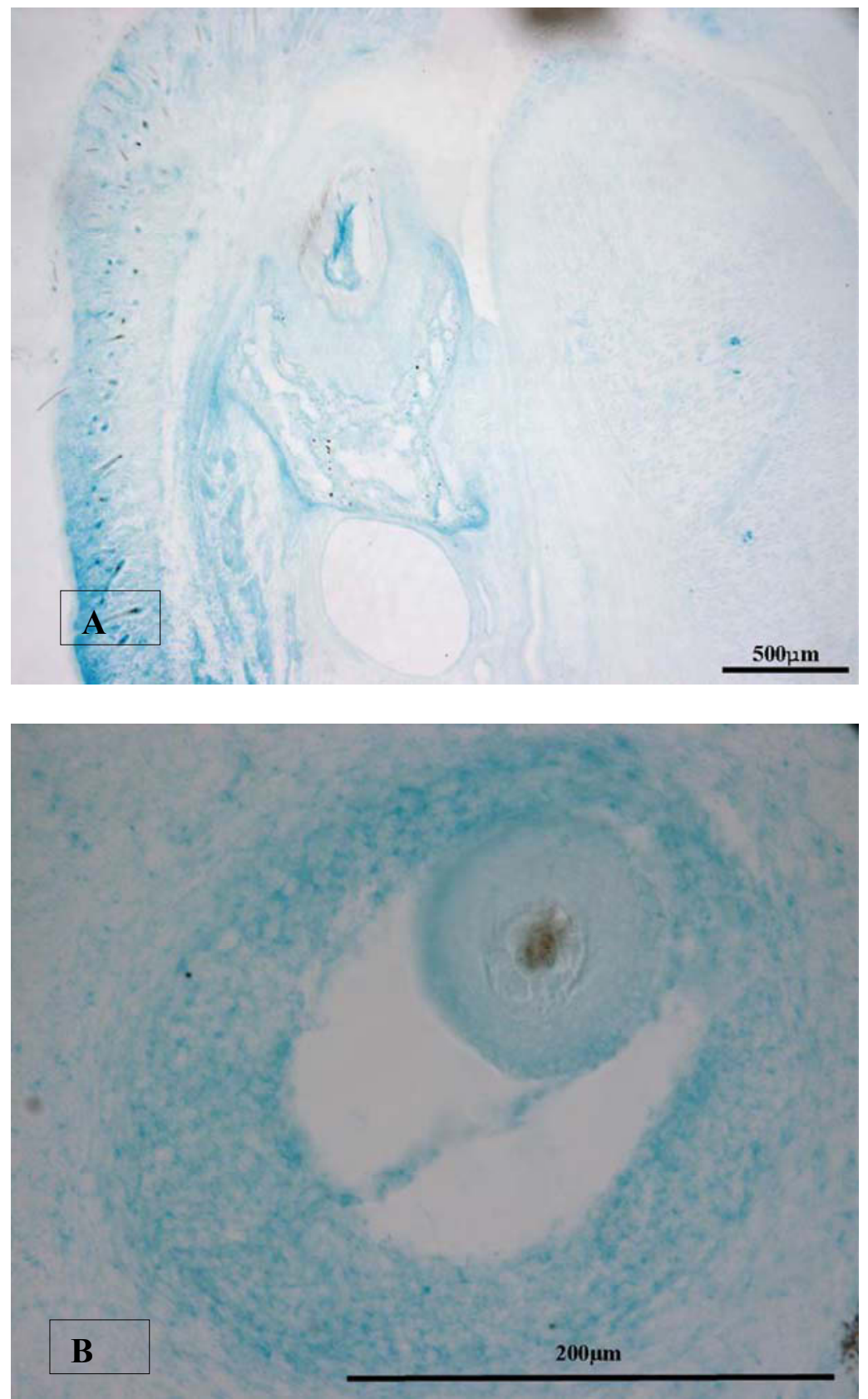

Figure 4.3: X-Gal Stained Vibrissae at Various Magnifications.

The above images were obtained at various magnifications (A-4x, B-40x). 

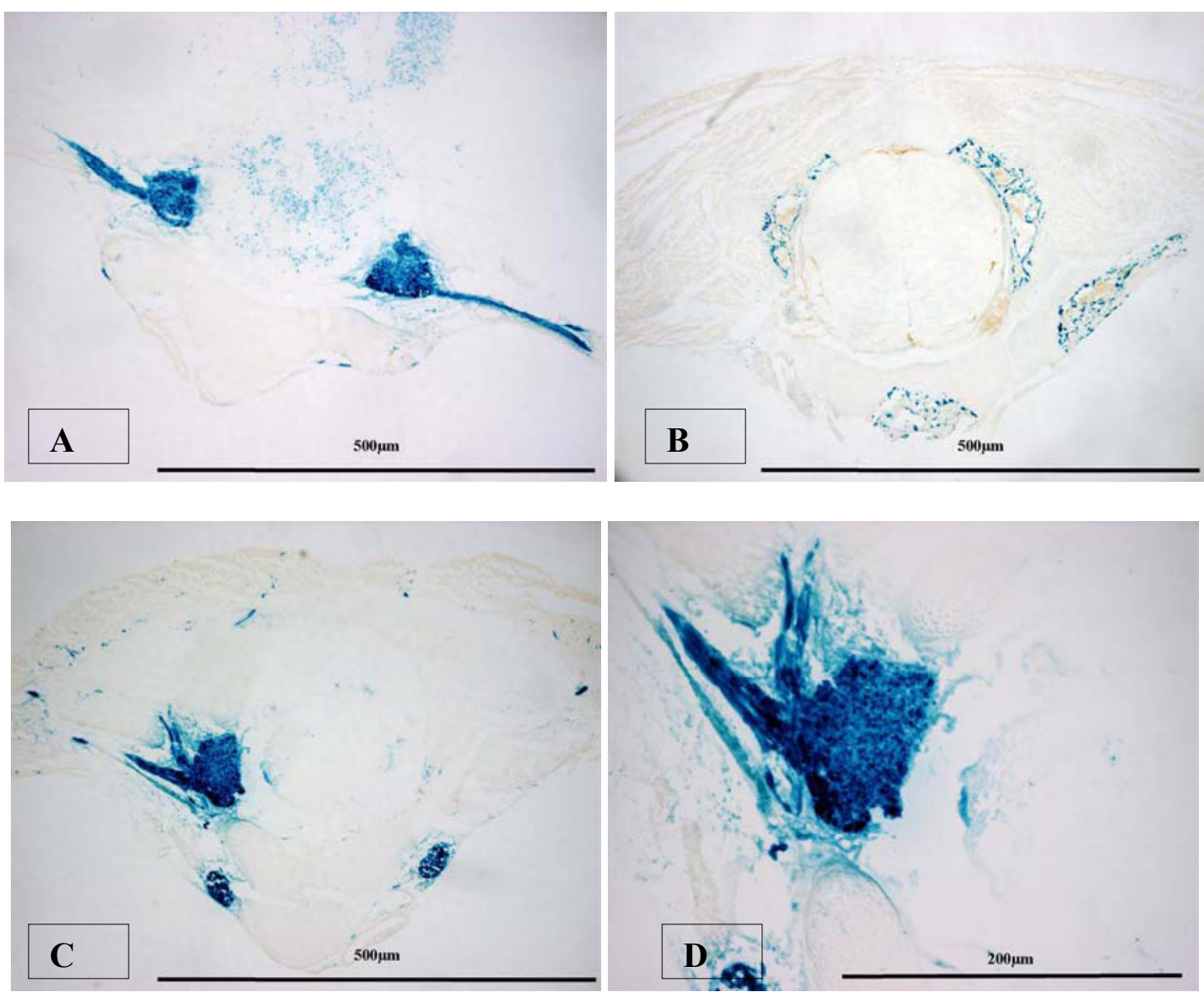

Figure 4.4: X-Gal Stained Dorsal Root Ganglia at Various Magnifications.

The above images were obtained at various magnifications (A-20x; B-20x; C-20x, D$40 \mathrm{x}$ ). Figures 4.4A, 4.4C, and 4.4D demonstrate $\mathrm{X}$-gal stained dorsal root ganglia in experimental mice while $4.4 \mathrm{~B}$ represents control mice. 

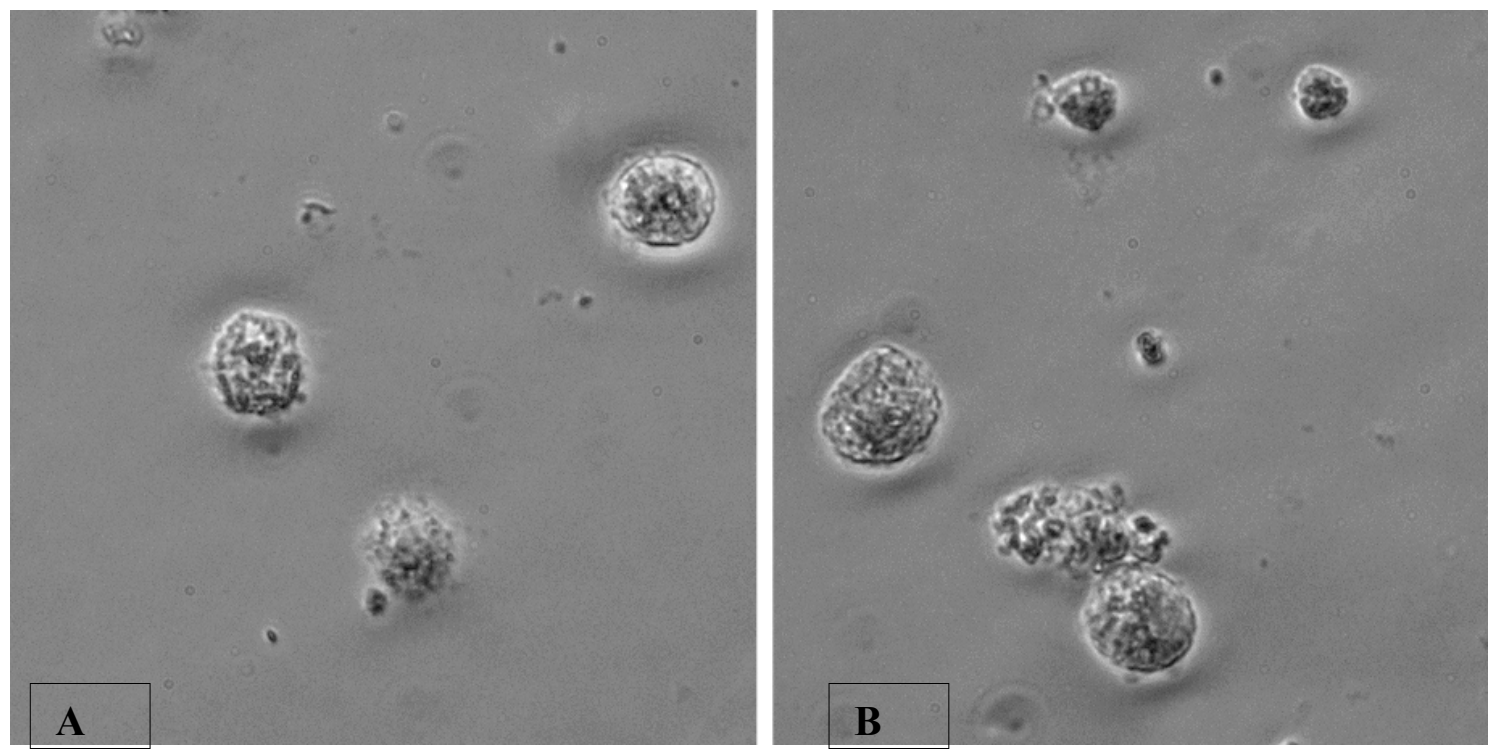

Figure 4.5: Formation of Neurospheres.

Formation of neurospheres was one of the indications for the presence of stem cells in cultured cells from the dental pulp. 

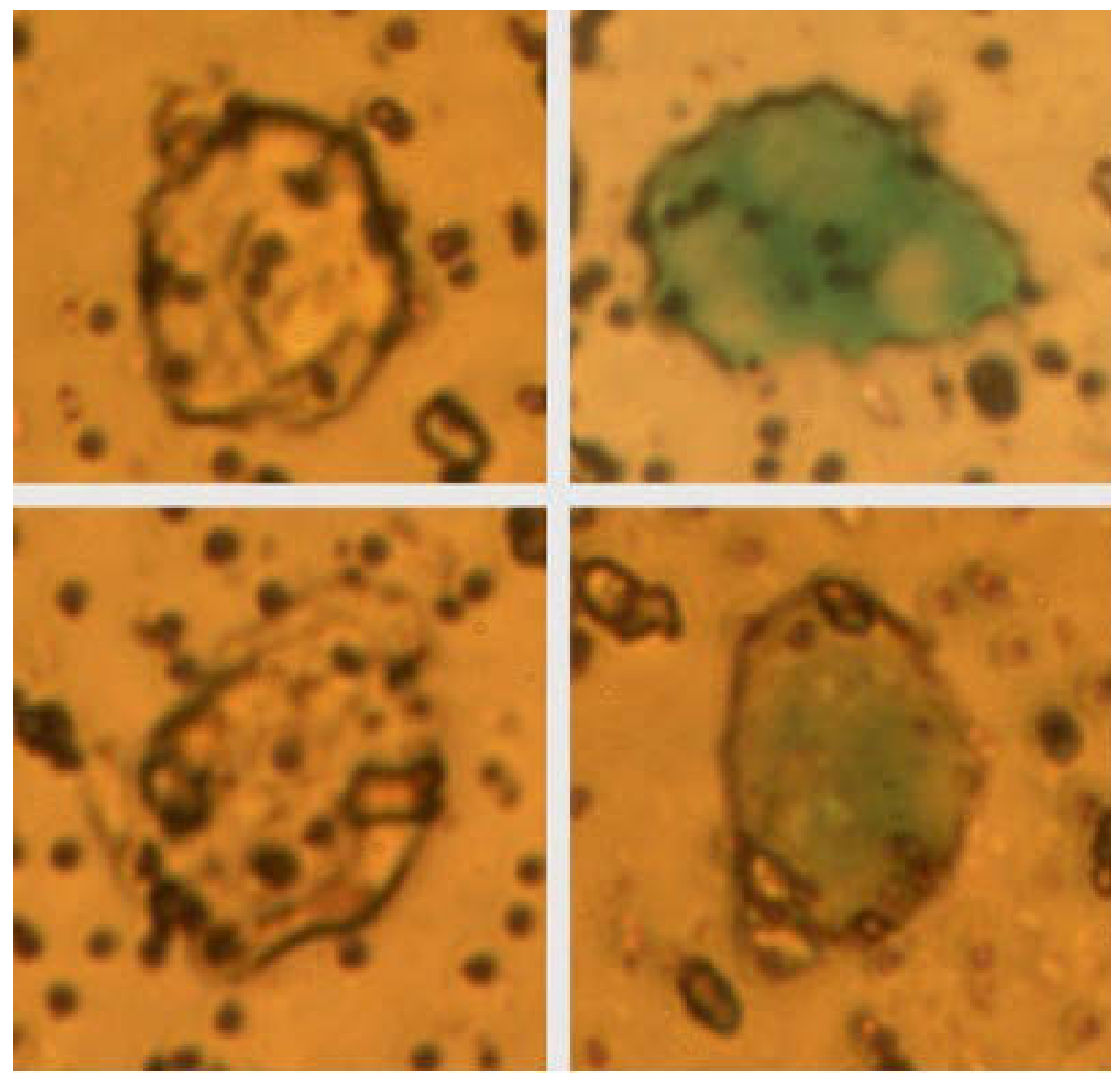

Figure 4.6: X-Gal Staining in Neurospheres.

$\mathrm{X}$-gal staining was observed in neurospheres generated from the experimental and control mice. 


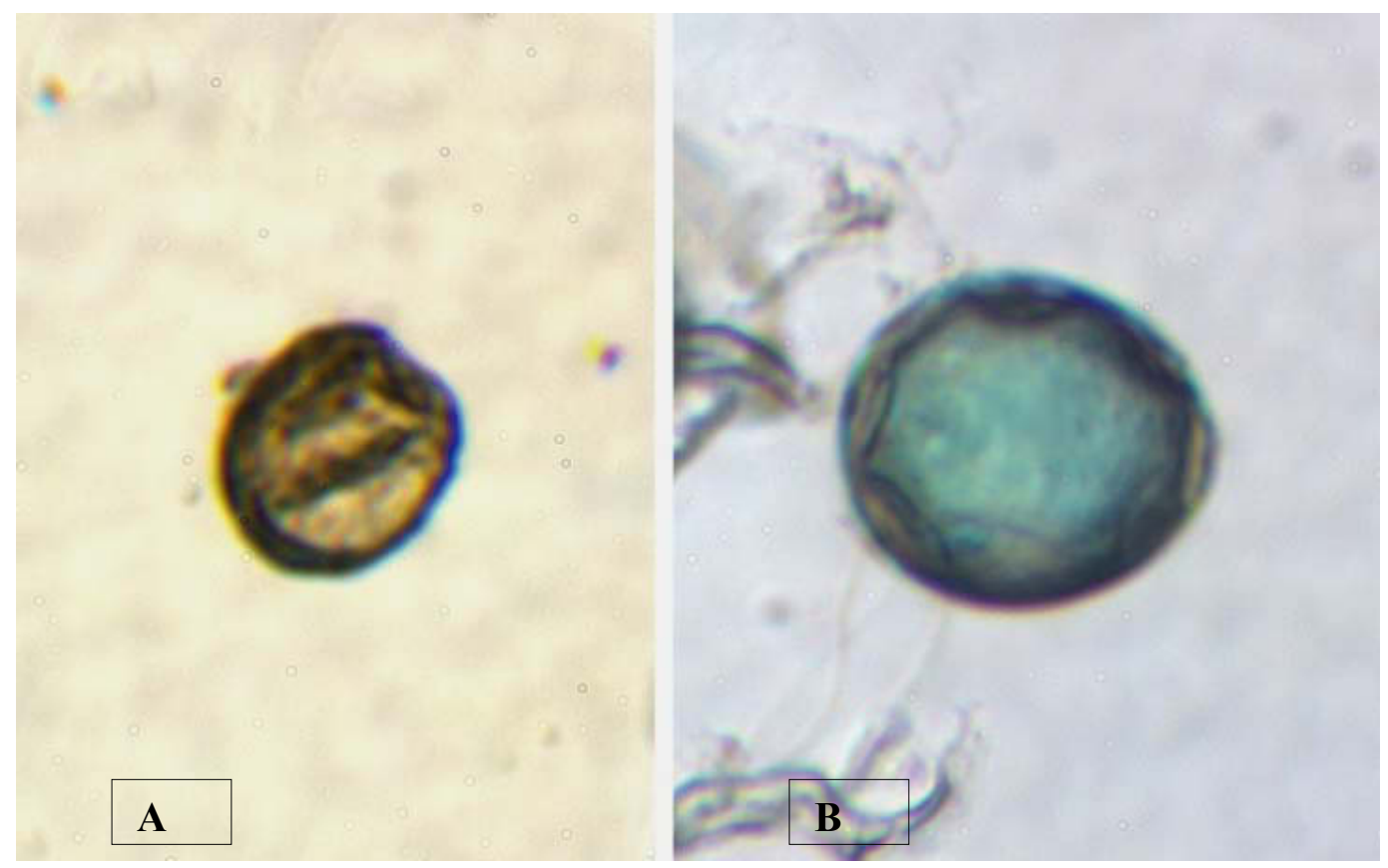

Figure 4.7: Enlarged View of X-Gal Stained Neurospheres.

$\mathrm{X}$-gal staining was observed in neurospheres generated from the experimental and control mice at different magnifications. 


\section{ORIGIN OF DENTAL PULP STEM/PROGENITOR CELLS}

Dental pulp cells were cultured from both doubly transgenic and wild type mice and were analyzed for the presence of neural crest derived cells, as well as cells with mesodermal origin in the cultures. The neurospheres were stained with X-gal and Nuclear Fast Red stain, as seen in Figure 4.8.

\section{CONTRIBUTION OF NEURAL CREST CELLS TO ALVEOLAR BONE, TONGUE AND TMJ}

Sagital sections of embryonic mice (E18) and post-natal mice (P7) were stained by X-gal staining to study the contribution of neural crest cells to the alveolar bone, tongue and temporomandibular joint. Condensation of neural crest derived tissue was seen in the mesenchyme underlying tongue epithelium, dental follicle, dental papilla (Figures 4.9, 4.10, 4.11, 4.12) magnified view of nerve ganglia in the tongue cross section, trigeminal ganglion, connective tissue in the palate, alveolar bone, Meckel's cartilage, hyoid bone, hyaline cartilage and the area of TMJ demonstrated the highly positive staining. 

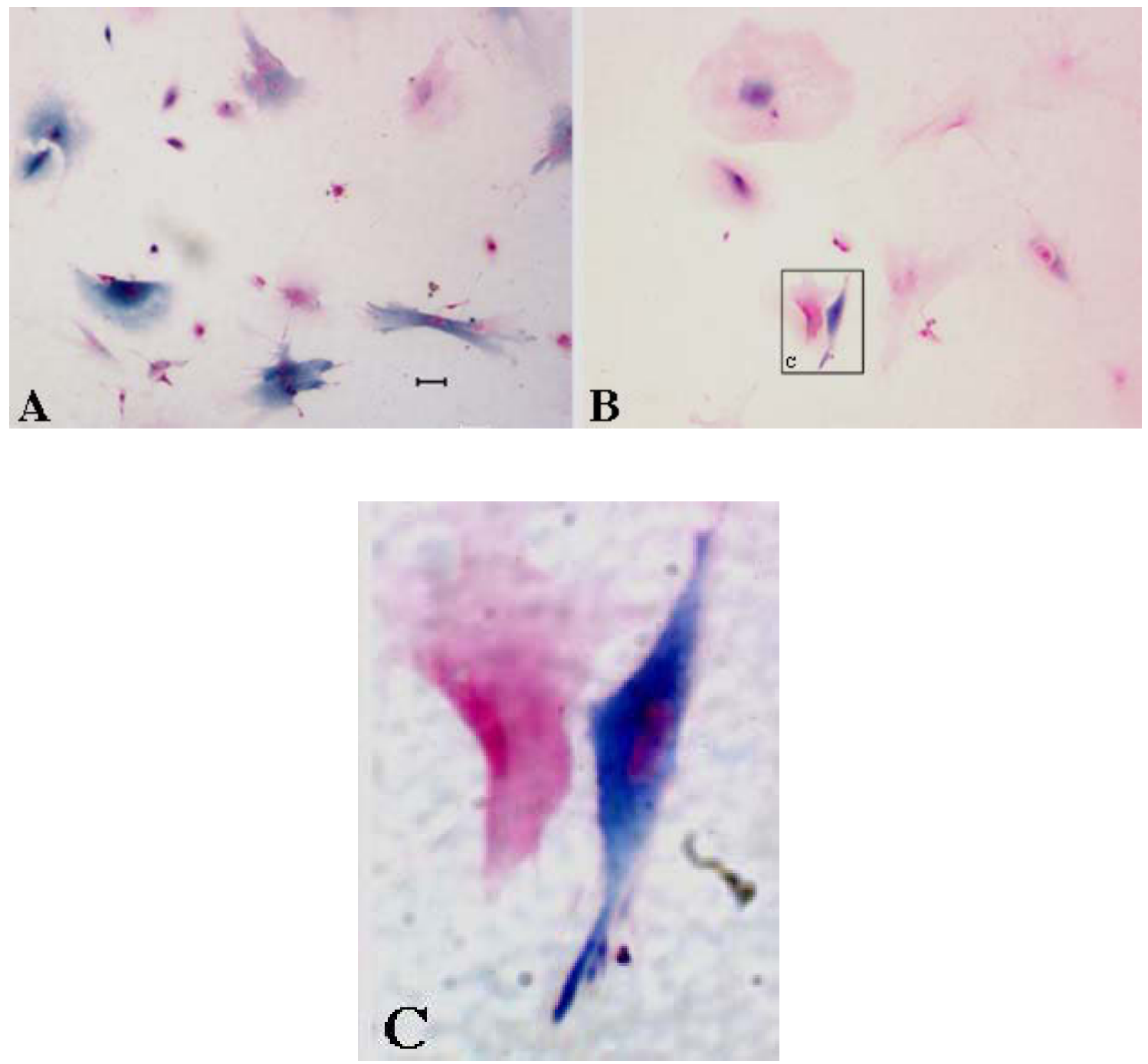

Figure 4.8: Dental Pulp Cells Stained with X-Gal and Nuclear Fast Red. Cultured dental pulp cells contain a mixture of neural crest-derived (blue) and mesodermal cells (Red). C is a higher magnification of the boxed area in B, showing two cells with different origins side by side. Cells retain lacZ expression for extended periods of times (several months) in culture. 

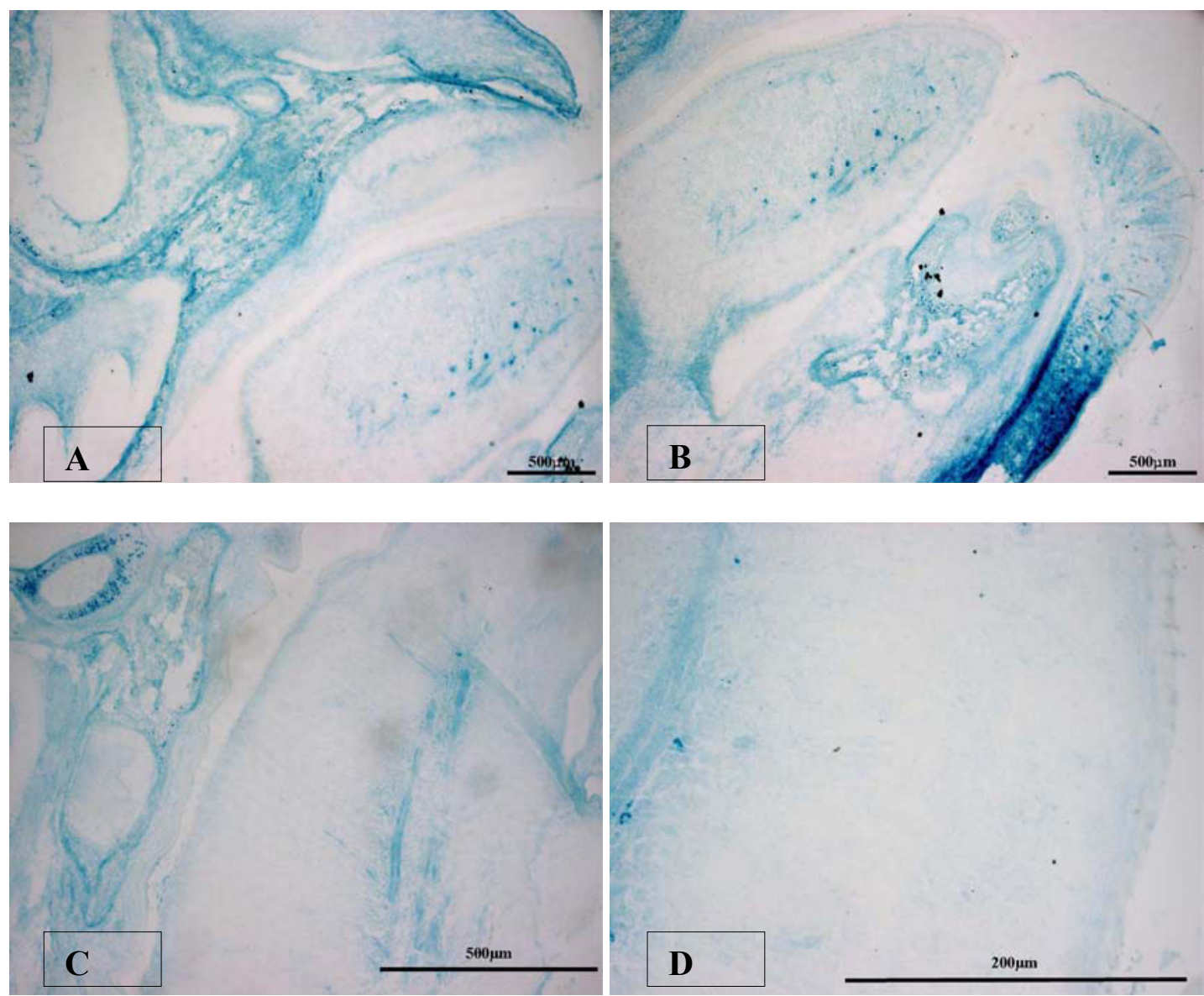

Figure 4.9: Magnified View of X-Gal Stained Tongue and Surrounding Tissues. The above images were obtained at various magnifications $(\mathrm{A}-4 \mathrm{x}, \mathrm{B}-4 \mathrm{x}, \mathrm{C}-10 \mathrm{x}$, and D40x). 

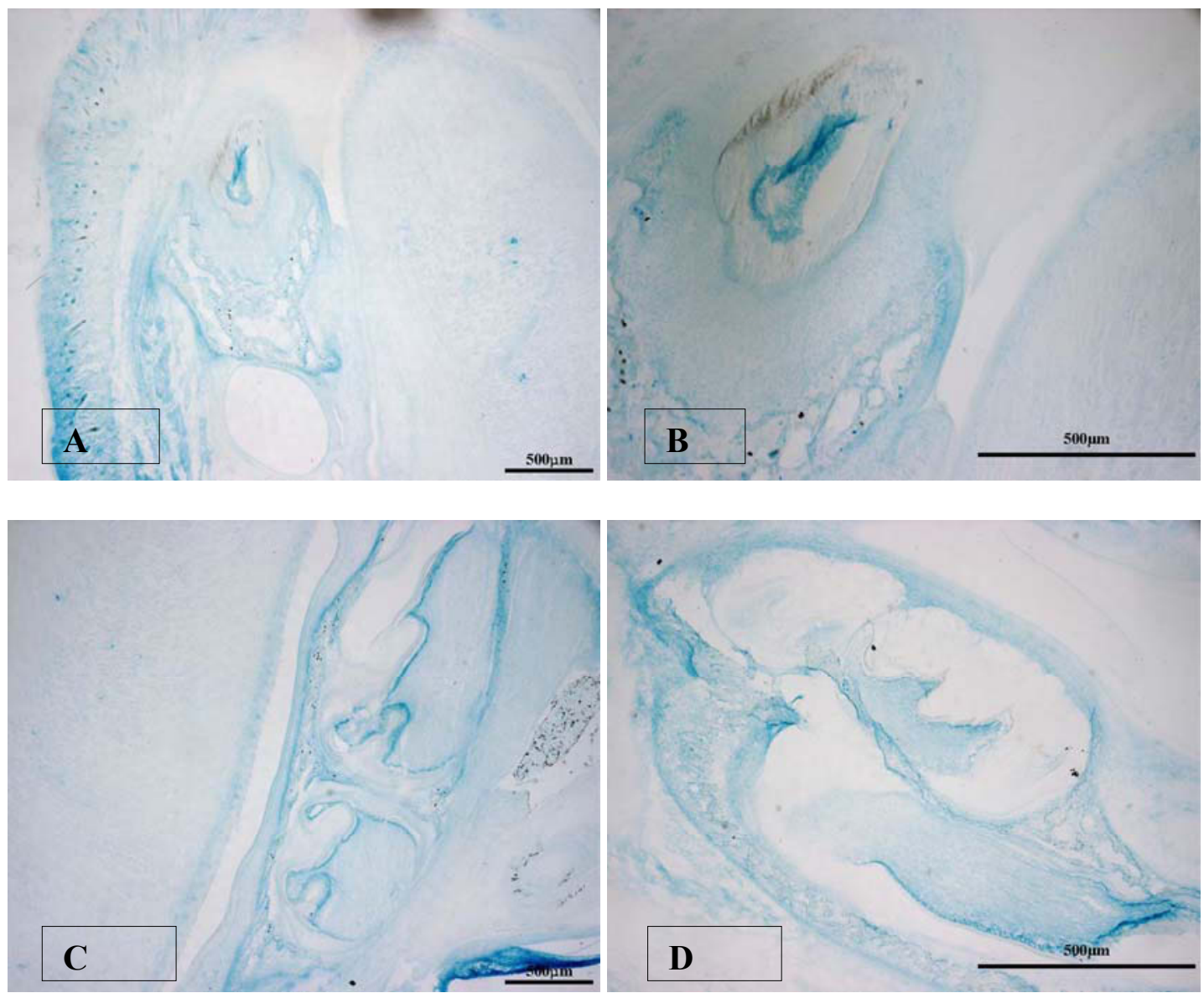

Figure 4.10: Magnified View of X-Gal Stained Developing Teeth, Alveolar Bone and Tongue.

The above figures were obtained at various magnifications (A-4x, B-10x, C-4x, and D10x). 

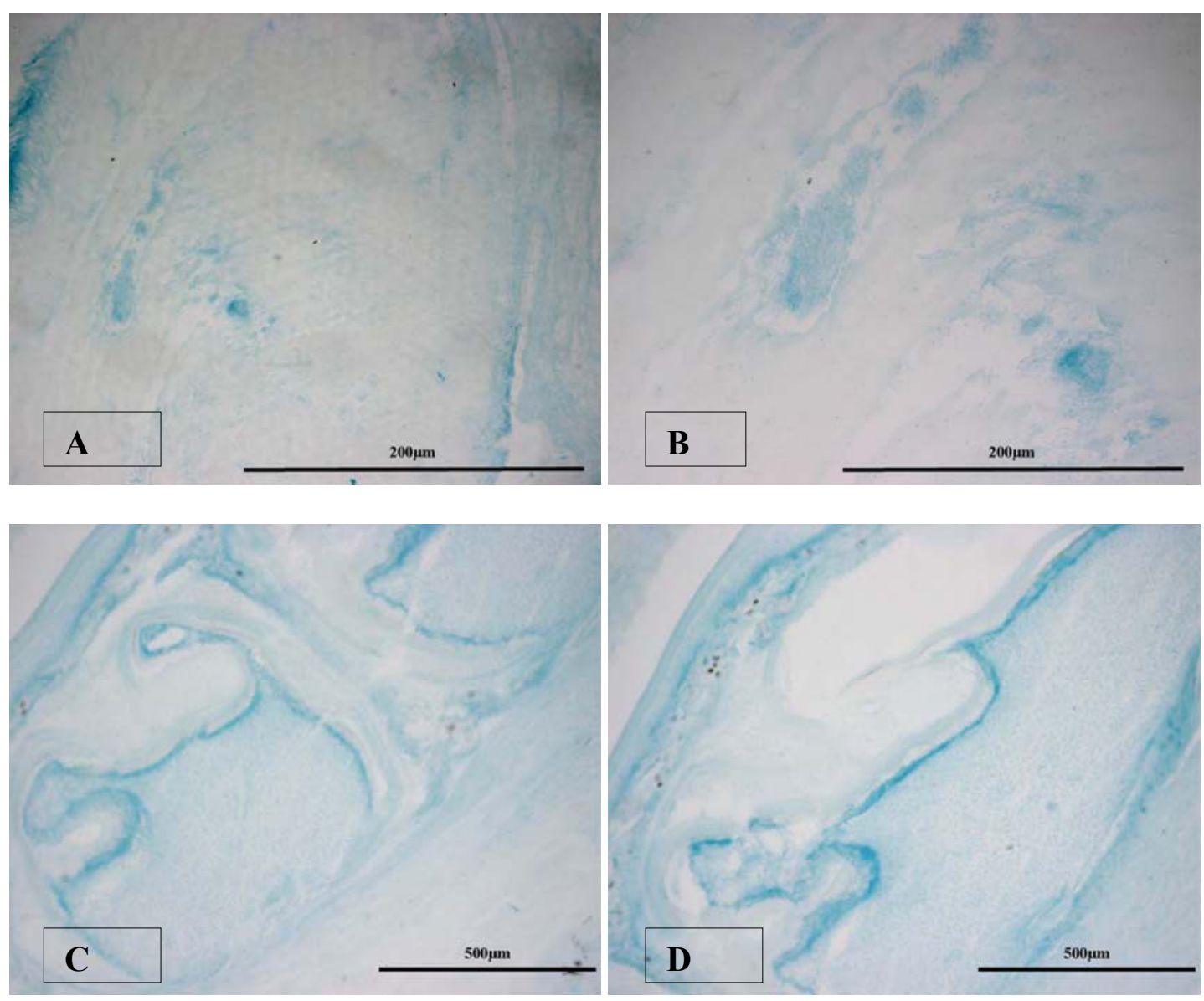

Figure 4.11: Magnified View of X-Gal Stained Tongue and Teeth.

The above images were obtained at various magnifications (A-40x, B-40x, C-10x, and D-10x). 

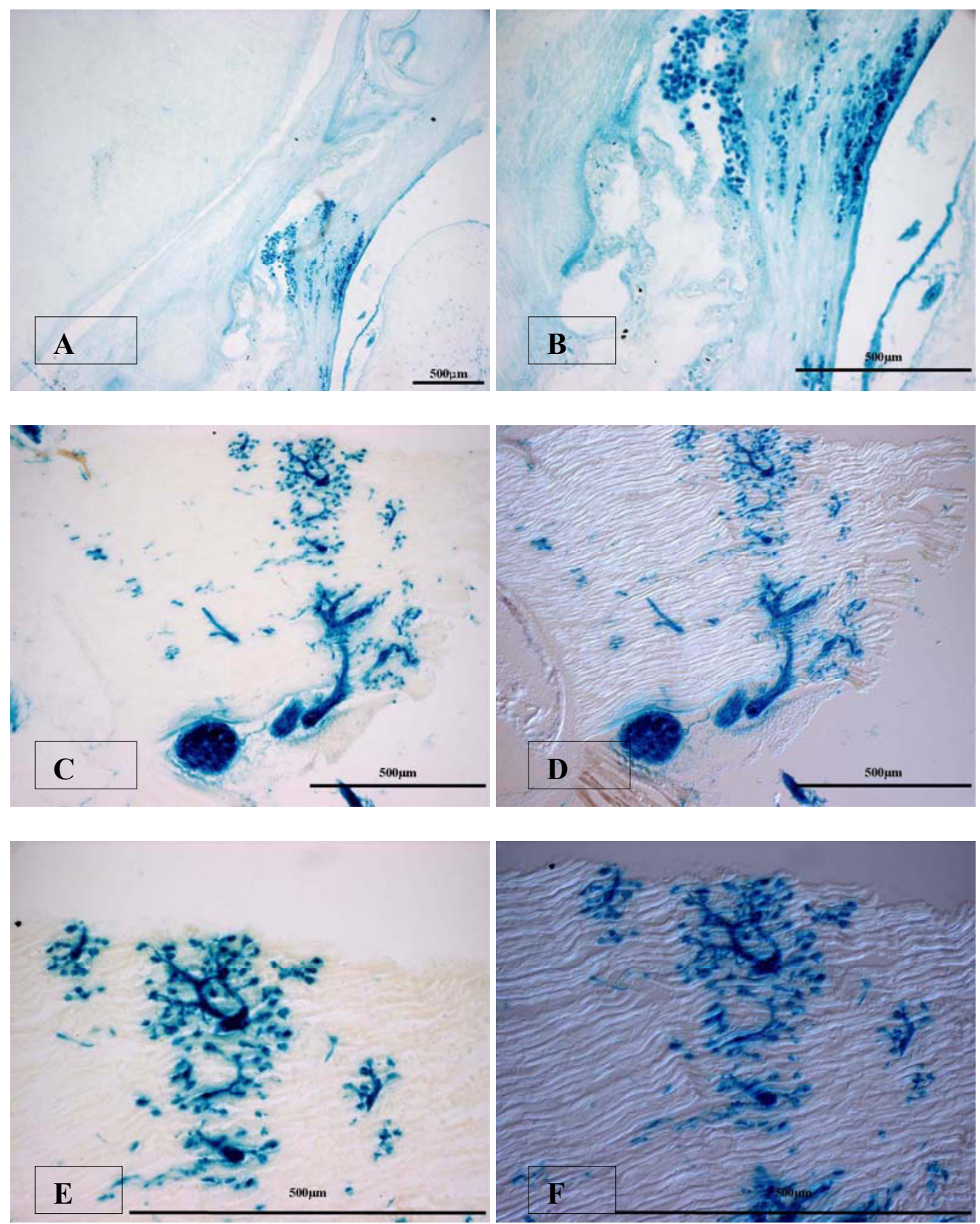

Figure 4.12: Magnified View of X-Gal Stained Trigeminal Ganglion and Surrounding Tissues.

The above images were obtained at various magnifications and Nomarski view (A-4x, B-10x, C-10x, D-10x Nomarski view, E-20x, and F-20x Nomarski view). 


\section{CHAPTER 5: DISCUSSION}

Dental pulp stem/progenitor cells (DPSC) have received extensive media attention during the past few years. Their discovery (Gronthos et al., 2000; 2002; Miura et al., 2003) as well as their proposed uses in spinal cord injury (Nosrat et al., 2001) and neurodegenerative diseases (Nosrat et al., 2004) raised expectations among the general public as well as professionals of possible therapies utilizing dental pulp cells. Development of successful therapies and approval for such approach by the Federal Drug Administration (FDA) requires thorough understanding of the origin and biological properties of DPSC. The results of this study entailed are of significant interest to the fields of adult stem cell research and dental pulp biology.

Wnt1 gene is only expressed in neural crest cells outside of the midbrain and the dorsal neural tube (Parr et al., 1993; Danielian et al., 1997; Ikeya et al., 1997). Transgenic models using targeted cells which co-express the lac $Z$ gene have a major advantage that they can be distinguished both in whole mount preparation and in the histological sections by $\beta$-galactosidase (X-gal) staining enabling a simple and accurate technique of labeling progenitor cells. Wnt1-Cre loxP $\mathrm{ROSA}^{+}$mice will therefore exhibit $\beta$-galactosidase (X-gal) staining specifically in neural crest-derived cells and tissues. In this study, the presence of neural crest-derived DPSC in postnatal mice (ranging from three days to three weeks) was determined using Cre recombinase fate mapping and cell culture techniques. PCR genotyping was utilized to isolate the experimental and control animals (Figure 4.2). X-gal staining (blue staining) of the tissues confirmed that Cre-mediated recombination had occurred in other neural crest derived tissues such as dorsal root ganglia (Figure 4.3A-B and Figure 4.5A-D) and the dermal papillae of whisker follicles (Figure 4.3C-D and Figure 4.4A-B) of the experimental animals.

Label retaining progeny and neurosphere forming abilities are indicative of stem/progenitor cell characteristics. In order to determine the regenerative potential of dental pulp stem/progenitor cells, the cells from both double transgenic and wild type mice were cultured for several months and the neurospheres were generated. We could demonstrate neurosphere formation from cultured dental pulp cells, as reported before (Gronthos et al., 2002; Sasaki et al., 2008; Stevens et al., 2008). Thus, we showed that cultured dental pulp cells from mice demonstrated neurosphere formation, indicating multipotent ability characteristic of stem/progenitor cells (Figure 4.6). These findings validate the view that the dental pulp is a niche of stem/progenitor cells (Gronthos et al., 2000; 2002; Sasaki et al., 2008). The results obtained from X-gal staining clearly demonstrated that neurospheres obtained from Wnt1-Cre ${ }^{+}$loxP $\mathrm{ROSA}^{+}$were blue colored, thus implying their neural crest lineage. Xgal stained stem/progenitor cells expressed lac $Z$, which indicated that such cells originated from neural crest, while the neurospheres obtained from the wild type mice were negatively stained and demonstrated no blue color (Figure 4.7 and Figure 4.8). Therefore, it was confirmed that neural crest derived stem/progenitor cells are present in the dental pulp tissue. 
One of the hypotheses examined in this study was that there are two distinct populations of adult stem/progenitor cells in the dental pulp, originating separately from the mesoderm and from the neural crest. Cultured neurospheres derived from dental pulp cells of $W n t 1-C r e^{+}$loxP $\mathrm{ROSA}^{+}$mice contained a mixture of neural crestderived (blue) and mesodermal (red) cells, validating the presence of multipotent progenitors of both NC and mesodermal origin within dental pulp (Figure 4.9). Therefore, it was confirmed that neural crest derived cells as well as cells with mesodermal origin are present in the dental pulp tissue. These results were highly reproducible, and success rate of generating double transgenic mice ( $\mathrm{Wnt} 1-\mathrm{Cre} \mathrm{l}^{+}$oxP $\mathrm{ROSA}^{+}$) was high. Our findings validate the presence of CNSC within the dental pulp, and support the view that dental pulp is possibly an easily accessible source of stem/progenitor cells with neurogenic potential, which may have potential applications in managing neurological disorders (Arthur et al., 2009). Further studies and in vivo evidence is needed to explore this area.

A possible approach for regenerative medicine involves using undifferentiated, multipotent adult stem/progenitor cells as a renewable source for replacement of lost or damaged cells and tissues. Adult stem/progenitor cells are an attractive therapeutic choice because they can be harvested for use as autologous grafts, thereby avoiding the possibility of rejection associated with allogeneic grafts. Dental pulp represents an easily accessible source of adult stem/progenitor cells that can be harvested from deciduous and permanent teeth (Gronthos et al., 2000; 2002; Miura et al., 2003), a property that makes dental pulp cells particularly interesting in tissue engineering from a therapeutic standpoint (Nosrat et al., 2001; 2004). The therapeutic potential of DPSC however, is contingent on understanding their origin and biological characteristics as well as factors regulating their differentiation.

The craniofacial skeleton has a complex developmental history, in that it is a mosaic of bony elements derived from the cranial neural crest and the paraxial mesoderm, which forms bone through both endochondral and intramembranous ossification (Couly et al., 1993; Chai et al., 2000; Jiang et al., 2002). Alveolar bone provides the support for a functional dentition, and it can be reshaped based on the precise needs of the tooth. Development of the alveolar bone involves CNCC-derived mesenchymal cell condensation to form the dental sac, osteoid deposition and mineralization (Chai, 2000; Sodek, 2000). The presence of CNSC in murine mandibular process has been demonstrated before (Zhang et al., 2006). The temporomandibular joint (TMJ) is one of the most complicated joints in the body. The development of temporomandibular joint the embryo has always been disputed. While, some researchers believe that the joint forms within a single mesenchymal condensation that differentiates into temporal and mandibular portions in response to a morphogenetic field, others support the hypothesis that the joint forms from two mesenchymal condensations; a temporal or glenoid blastema associated with the temporal bone and a condylar blastema associated with the mandible each growing slowly towards the other. The increasing number of patients with TMJ disorders is of clinical relevance and implies an important treatment target for dentistry. Thus, a clear 
understanding of the embryonic development of TMJ may help to clarify the etiology, development and treatment of TMJ disorders. The tongue is a specialized muscular organ that is primarily involved in taste but also assists in speech. It develops from neural crest derived pharyngeal arches. The delineation of $\mathrm{CNC}$ contributions and related local morphogenetic signaling patterns can help deduce genetic pathways involved in congenital craniofacial anomalies affecting these structures.

In order to determine the contribution of neural crest cells to alveolar bone, tongue and the TMJ, the sagital sections obtained from the control and the experimental embryonic mice and postnatal mice were stained with X-gal staining technique. The blue staining in the alveolar bone, tongue, and the area around the temporomandibular joint (Figure 4.9, 4.10, 4.11, and 4.12) in the embryonic (E18) and the postnatal (P7) mice indicated the presence of neural crest derived cells in the alveolar bone, tongue and the area around the temporomandibular joint. Thus, our results demonstrated the presence of cells of neural crest cell lineage in alveolar processes, area around the temporomandibular joint and tongue in postnatal transgenic mice. Elucidating the extent of $\mathrm{CNC}$ contribution to patterning of these craniofacial tissues and their regulators is of potential relevance towards a better understanding of developmental anomalies and also for development of craniofacial tissue engineering therapeutics. Key differences in fetal developmental events between the cranial and appendicular skeleton may have therapeutic implications in regenerative medicine. These results imply a possibility for the utilization of neural crest cells in the repair and regeneration of pathologic conditions associated with these tissues, although much further research is needed in this subject. The presence of CNSC within dental tissues is relevant towards the possible utilization of CNSC in craniofacial regeneration and tissue engineering is therefore, a beneficial thrust area in craniofacial research. 


\section{CHAPTER 6: CONCLUSIONS}

The results of the study suggest that:

1. Neural crest-derived stem/progenitor cells are present in the dental pulp of embryonic and postnatal transgenic mice.

2. Dental pulp cells form neurospheres when cultured under neurosphere forming conditions (Neurobasal A, B-27, EGF, bFGF).

3. Dental pulp cells were cultured for several months and our analysis demonstrated that neural crest derived cells as well as cell with mesodermal origin are present in the cultures.

4. Neural crest cell contribute in the formation of dental pulp, alveolar processes, tongue and the area of the temporomandibular joint in embryonic as well as postnatal mice. 


\section{CHAPTER 7: LIMITATIONS AND FUTURE APPLICATIONS}

Although X-gal staining is a fairly well established technique, in this particular study it was difficult to eliminate the non-specific X-gal staining in the surrounding tissues. Another limitation of this study was that one of the objectives in the hypothesisthat neural crest cells contribute to the temporomandibular joint-could not be proved due to the sensitivity of the technique.

The results of this study indicate that neural crest cells contribute to the developing teeth, alveolar bone, tongue and areas of TMJ. Therefore, future studies can be focused more towards determining the specific contributions of these cells to the TMJ. Long-term applications of this study will be to develop treatment modalities for dental and temporomandibular joint disorders. 


\section{LIST OF REFERENCES}

Abe S, Yamaguchi S, Amagasa T. Multilineage cells from apical pulp of human tooth with immature apex. Oral Sci Int 2007; 4: 45-58.

Abzhanov A, Tzahor E, Lassar AB, Tabin CJ. Dissimilar regulation of cell differentiation in mesencephalic and sacral neural crest cells in vitro. Development 2003; 130: 4567-4579.

Albers B. Competence as the main factor determining the size of the neural plate. Dev Growth Diff 1987; 29: 535-545.

Anderson DJ. Cellular and molecular biology of neural crest cell lineage determination. Trends Genet 1997; 13: 276-280.

Arthur A, Shi S, Zannettino AC, Fujii N, Gronthos S, Koblar SA. Implanted adult human dental pulp stem cells induce endogenous axon guidance. Stem Cells 2009; 27: 2229-2237.

Baetge G, Gershon MD. Transient catecholaminergic (TC) cells in the vagus nerves and bowel of fetal mice: relationship to the development of enteric neurons. Dev Biol 1990; 132: $189-211$.

Baker CV, Bronner-Fraser M. Vertebrate cranial placodes I. Embryonic induction. Dev Biol 2001; 232: 1-61.

Baroffio A, Dupin E, Le Douarin NM. Common precursors for neural and mesectodermal derivatives in the cephalic neural crest. Development 1991; 112: 301305.

Bithell A, Williams BP. Neural stem cells and replacement therapy-making the right cells. Clinical Sci 2005; 108: 13-22.

Bixby S, Kruger GM, Mosher JT, Joseph NM, Morrison SJ. Cell-intrinsic differences between stem cells from different regions of the peripheral nervous system regulate the generation of neural diversity. Neuron 2002; 35: 643-656.

Bronner-Fraser M, Fraser SE. Cell lineage analysis reveals multipotency of some avian neural crest cells. Nature 1988; 335: 161-164.

Bronner-Fraser M. Origin of the avian neural crest. Stem Cells 1995; 13: 640-646.

Burstyn-Cohen T, Stanleigh J, Sela-Donenfeld D, Kalcheim C. Canonical Wnt activity regulates trunk neural crest delamination linking $\mathrm{BMP} /$ noggin signaling with $\mathrm{G} 1 / \mathrm{S}$ transition. Development 2004; 131: 5327-5339. 
Burt DW, Cheng HH. The chicken gene map. Inst Lab Anim Res J 1998; 39: 229-236.

Chai H, Lee JJ, Constantino PJ, Lucas PW, Lawn BR. Remarkable resilience of teeth. Proc Natl Acad Sci USA 2009; 106: 7289-7293.

Chai Y, Ito Y, Han J. TGF-beta signaling and its functional significance in regulating the fate of cranial neural crest cells. Crit Rev Oral Biol Med 2003; 14(2): 78-88.

Chang C, Hemmati-Brivanlou A. Neural crest induction by XWnt7B in Xenopus. Dev Biol 1998; 194: 129-134.

Chávez-Lomeli ME, Mansilla Lory J, Pompa JA, Kjaer I. The human mandibular canal arises from three separate canals innervating different tooth groups. J Dent Res 1996; 75: $1540-1544$.

Cho SW, Hwang HJ, Kim JY, Song WC, Song SJ, Yamamoto H, Jung HS. Lineage of non-cranial neural crest cell in the dental mesenchyme: using a lac $Z$ reporter gene during early tooth development. J Electron Microsc (Tokyo) 2003; 52: 567-571.

Chung IH, Yamaza T, Zhao H, Choung PH, Shi S, Chai Y. Stem cell property of postmigratory cranial neural crest cells and their utility in alveolar bone regeneration and tooth development. Stem Cells 2009; 27: 866-877.

Couly G, Creuzet S, Bennaceur S, Vincent C, Le Douarin NM. Interactions between Hox-negative cephalic neural crest cells and the foregut endoderm in patterning the facial skeleton in the vertebrate head. Development 2002; 129: 1061-1073.

Crane JF, Trainor PA. Neural crest stem and progenitor cells. Annu Rev Cell Dev Biol 2006; $22: 267-286$.

Creuzet S, Couly G, Le Douarin NM. Patterning the neural crest derivatives during development of the vertebrate head: insights from avian studies. J Anat 2005; 207: 447459.

Creuzet S, Couly G, Vincent C, Le Douarin NM. Negative effect of Hox gene expression on the development of the neural crest-derived facial skeleton. Development 2002; 129: 4301-4313.

De Calisto J, Araya C, Marchant L, Riaz CF, Mayor R. Essential role of non-canonical Wnt signaling in neural crest migration. Development 2005; 132: 2587-2597.

Dupin E, Calloni G, Real C, Gonçalves-Trentin A, Le Douarin NM. Neural crest progenitors and stem cells. C R Biol 2007; 330: 521-529.

Dupin E, Sextier-Sainte-Claire Deville F, Nataf V, Le Douarin NM.The ontogeny of the neural crest. C R Acad Sci III 1993; 316: 1062-1081. 
Erickson CA, Perris R. The role of cell-cell and cell-matrix interactions in the morphogenesis of the neural crest. Dev Biol 1993; 159: 60-74.

Florica-Howells E, Maroteaux L, Gershon M. D'5-HT2B receptors are expressed by neuronal precursors in the enteric nervous system of fetal mice and promote neuronal differentiation. Ann N Y Acad Sci 1998; 861: 246.

Gans C, Northcutt RG. The genesis of neural crest and epidermal placodes: a

reinterpretation of vertebrate origins. The Quarterly Reviews of Biology 1983; 58: 1-21.

García-Castro MI, Marcelle C, Bronner-Fraser M. Ectodermal Wnt function as a neural crest inducer. Science 2002; 297(5582): 848-851.

Graham A, Heyman I, Lumsden A.Even-numbered rhombomeres control the apoptotic elimination of neural crest cells from odd-numbered rhombomeres in the chick hindbrain. Development 1993; 119(1): 233-245.

Gronthos S, Mankani M, Brahim J, et al. Postnatal human dental pulp stem cells (DPSCs) in vitro and in vivo. Proc Natl Acad Sci USA 2000; 97: 13625-13630.

S, Brahim J, Li W, Fisher L W, Cherman N, Boyde A, DenBesten P, Robey P Gehron Shi S. Stem cell properties of human dental pulp stem cells. J Dent Res 2002; 81: 531535.

Groves AK, Bonner-Fraser M. Competence, specification and commitment in otic placode induction. Development 1999; 127: 3489-3499.

Hall BK, Hörstadius S. The neural crest. Oxford: Oxford University Press 1988.

Hall BK. The neural crest in development and evolution. New York: Springer 1999.

Hari L, Brault V, Kléber M, Lee HY, Ille F, Leimeroth R, Paratore C, Suter U, Kemler $\mathrm{R}$, Sommer L. Lineage-specific requirements of beta-catenin in neural crest development. J Cell Biol 2002; 159: 867-880.

Helms JA, Schneider RA. Cranial skeletal biology. Nature 2003; 423: 326-331.

His, W. Untersuchungen über die erste Anlage des Wirbeltierleibes. Die erste Entwicklung ds Hühnchens im Ei. Leipzig, F.C.W. Vogel 1868.

Huang CY, Pelaez D, Bendala JD, Garcia-Godoy F, Cheung HS. Plasticity of stem cells derived from adult periodontal ligament. Regen Med 2009; 4: 809-821.

Jiang HB, Tian WD, Liu LK, Xu Y. In vitro odontoblast like cell differentiation of cranial neural crest cells induced by fibroblast growth factor $\mathrm{b}$ and dentin noncollagenous proteins. Cell Biol Int 2008; 32: 671-678. 
Johansson CB, Momma S,Clarke DL, Risling M. Lendhal U, Frisen J. Identification of a neural stem cell in adult mammalian central nervous system. Cell 1999; 96: 25-34.

Joseph NM, Mukouyama, Mosher, et al. Neural crest stem cells undergo multilineage differentiation in developing peripheral nerves to generate endoneurial fibroblasts in addition to Schwann cells. Development 2004; 131: 5599-5612.

Kanzler B, Foreman RK, Labosky PA, Mallo M. BMP signaling is essential for development of skeletogenic and neurogenic cranial neural crest. Development 2000; 127: 1095-1104.

Keynes RJ, Stern CD. Segmentation in the vertebrate nervous system. Nature 1984; 310: 786-789.

Kjaer I, Kocsis G, Nodal M, Christensen LR. Etiological aspects of mandibular tooth agenesis-focusing on the role of nerve, oral mucosa, and supporting tissues. Eur $\mathrm{J}$ Orthod 1994; 16: 371-375.

Kjaer I. Formation and early prenatal location of the human mental foramen. Scand $\mathbf{J}$ Dent Res 1989; 97: 1-7.

Kléber M, Sommer L. Wnt signaling and the regulation of stem cell function. Curr Opin Cell Biol 2004; 16: 681-687.

Köntges G, Lumsden A. Rhombencephalic neural crest segmentation is preserved throughout craniofacial ontogeny. Development 1996; 122: 3229-3242.

Kos HC. Cre/lox system for generating tissue specific gene knockout mouse models. Nutr Rev 2004; 62: 243-246.

Kos R, Reedy MV, Johnson RL, Erickson CA. The winged helix transcription factor FoxD3 is important for establishing the neural crest lineage and repressing melanogenesis in avian embryos. Development 2001; 128: 1467-1479.

LaBonne C, Bronner-Fraser M. Induction and patterning of the neural crest, a stem celllike precursor population. J Neurobiol 1998; 36: 175-189.

Larson WJ. Human embryology (2nd ed.) New York: Churchill-Livingstone 1997; 121122.

van de Lavoir MC, Diamond JH, Leighton PA, Mather-Love C, Heyer BS, Bradshaw R, Kerchner A, Hooi LT, Gessaro TM, Swanberg SE, Delany ME, Etches RJ. Germline transmission of genetically modified primordial germ cells. Nature 2006; 441: 766-769.

Le Douarin NM, Creuzet S, Couly G, Dupin E. Neural crest cell plasticity and its limits. Development 2004; 131: 4637-4650. 
Le Douarin NM, Dupin E. Multipotentiality of the neural crest. Curr Opin Genet Dev 2003; 13: 529-536.

Le Douarin NM, Dupin E, Ziller C. Genetic and epigenetic control in neural crest development. Curr Opin Genet Dev 1994; 4: 658-669.

Le Douarin N, Kalcheim C. The neural crest (2nd ed.) Cambridge New York Cambridge University Press, 1999.

Le Douarin NM, Ziller C. Plasticity in neural crest cell differentiation. Curr Opin Cell Biol 1993; 5: 1036-1043.

Lee G, Kim H, Elkabetz Y, Al Shamy G, Panagiotakos G, Barberi T, Tabar V, Studer L. Isolation and directed differentiation of neural crest stem cells derived from human embryonic stem cells. Nat Biotechnol 2007; 25: 1468-1675.

Lewis JL, Bonner J, Modrell M, Ragland JW, Moon RT, Dorsky RI, Raible DW. Reiterated $W n t$ signaling during zebrafish neural crest development. Development 2004; 131: 1299-1308.

Liem KF Jr., Tremml G, Roelink H, Jessell TM. Dorsal differentiation of neural plate cells induced by BMP-mediated signals from epidermal ectoderm. Cell 1995; 82: 969979.

Lo LC, Johnson JE, Wuenschell CW, Saito T, Anderson DJ. Mammalian achaete-scute homolog 1 is transiently expressed by spatially restricted subsets of early neuroepithelial and neural crest cells. Genes Dev 1991; 5: 1524-1537.

Lo L, Sommeer L, Anderson DJ. MASH 1 maintains competence for BMP 2- induced neuronal differentiation in post migratory neural crest cells. Current Biol 1997; 7: 440450 .

Lumsden A, Sprawson N, Graham A. Segmental origin and migration of neural crest cells in the hindbrain region of chick embryo. Development 1991; 101: 247-254.

Lwigale PY, Scneider RA. Other chimeras: quail duck and mouse chick. Methods. Cell Biol 2008; 87: 59-74.

Mancilla A, Mayor R. Neural crest formation in Xenopus laevis: mechanisms of Xslug induction. Dev Biol 1996; 177: 580-589.

Matthews HK, Broders-Bondon F, Thiery JP, Mayor R. Wnt 11r is required for cranial neural crest migration. Dev Dyn 2008; 237: 3404-3409.

Mayor R, Morgan R, Sargent MG. Induction of the prospective neural crest of Xenopus. Development 1995; 121: 767-777. 
Merill AE, Eames F, Weston SJ, Heath T, Schneider RA. Mesenchyme dependent BMP signaling directs mandibular osteogenesis. Development 2008; 135: 1223-1234.

Meulemans D, Bronner-Fraser M. Gene-regulatory interactions in neural crest evolution and development. Dev Cell 2004; 7: 291-299.

Mitsiadis TA, Angeli I, James C, Lendhal U, Sharpe PT. Role of Islet1 in patterning of murine dentition. Development 2003; 130: 4451-4460.

Miura M, Gronthos S, Zhao M, Lu B, Fisher LW, Robey PG, Shi S.SHED: stem cells from human exfoliated deciduous teeth. Proc Natl Acad Sci USA 2003; 100: 5807-5812.

Modino SAC, Sharpe PT. Tissue engineering of teeth using adult stem cells. Atch Oral Biol 2005; 50: 255-258.

Monsoro-Burq AH, Fletcher RB, Harland RM. Neural crest induction by paraxial mesoderm in Xenopus embryos requires FGF signals. Development 2003; 130: 31113124.

Monsoro-Burq AH, Wang E, Harland R. Msx1 and Pax3 cooperate to mediate FGF8 and WNT signals during Xenopus neural crest induction. Dev Cell 2005; 8: 167-178.

Morgan R, Sargent MG. The role in neural patterning of translation initiation factor eIF4AII; induction of neural fold genes.Development 1997; 124: 2751-2760.

Morita R, Nakao K, Oagawa M, Saji Y, Ishida K, Tsuji T. Pluripotent stem cells develop into regenerated tooth by organ grem method in combination with tooth germ derived epithelium. Int Sym Micro- Nano Mechatronics Hum Sci 2008; 203-207.

Morrison, White PM, Zock C and Anderson DJ. Prospective identification, isolation by flow cytometry, and in vivo self-renewal of multipotent mammalian neural crest stem cells. Cell 1999; 96: 737-749.

Morriss-Kay G, Tucket F. Early events in mammalian craniofacial morphogenesis. J Craniofac Genet Dev Biol 1991; 11: 181-191.

Morsczeck C, Völlner F, Saugspier M, Brandl C, Reichert TE, Driemel O, Schmalz G. Comparison of human dental follicle cells (DFCs) and stem cells from human exfoliated deciduous teeth (SHED) after neural differentiation in vitro. Clin Oral Investig $2009 \mathrm{Jul}$ 10 [Epub ahead of print].

Motohashi T, Aoki H, Chiba K, Yoshimura N, Kunisada T. Multipotent cell fate of neural crest-like cells derived from embryonic stem cells. Stem Cells 2007; 25: 402-410.

Moury JD, Jacobson AG. Neural fold formation at newly created boundaries between neural plate and epidermis in the axolotl. Dev Biol 1989; 133: 44-57. 
Moury JD, Jacobson AG. The origins of neural crest cells in the axolotl. Dev Biol 1990; 141: 243-253.

Murray JC, Schutte BC. Cleft palate: players, pathways, and pursuits. J Clin Invest 2004; 113: 1676-1678.

Nakao K, Morita R, Saji Y, Ishida K, Tomita Y, Ogawa M , Saitoh M. The development of a bio engineered organ germ method. Nat Met 2007; 4: 227-230.

Noden DM. The role of the neural crest in patterning of avian cranial skeletal, connective and muscle tissue. Dev Biol 1983; 96: 144-165.

Noden DM, Trainor PA. Relations and interactions between cranial meso- derm and neural crest populations. J Anat 2005; 207: 575-601.

Nosrat IV, Smith CA, Mullally P, Olson L, Nosrat CA. Dental pulp cells provide neurotrophic support for dopaminergic neurons and differentiate into neurons in vitro; implications for tissue engineering and repair in the nervous system. Eur J Neurosci 2004a; 19: 2388-2398.

Nosrat IV, Widenfalk J, Olson L, Nosrat CA. Dental pulp cells produce neurotrophic factors, interact with trigeminal neurons in vitro, and rescue motoneurons after spinal cord injury. Dev Biol 2001; 238: 120-132.

Ohazama A, Modino SA, Miletich I, Sharpe PT. Stem cell based tissue engineering of murine teeth. J Dent Res 2004; 100: 5807-5812.

Osumi-Yamashita N, Ninomiya Y, Doi H, Eto K. The contribution of both forebrain and midbrain to crest cells the mesenchyme in the frontonasal mass of mouse embryos. Dev Biol 1994; 164: 409-419.

Pachnis V, Mankoo B, Costantini F. Expression of the C-ret protooncogene during mouse embryogenesis. Development 1993; 119: 1005-1017.

Piotrowski T, Nüsslein-Volhard C. The endoderm plays an important role in patterning the segmented pharyngeal region in zebrafish (Danio rerio). Dev Biol 2000; 15: 225: $339-356$

Potten CS, Loeffler M. Stem cells: attributes, cycles; spirals, pitfalls and uncertainties. Lessons for and from the crypt. Development 1990; 110: 1001-1020.

Raible DW, Eisen JS. Restriction of neural crest cell fate in the trunk of the embryonic zebrafish. Development 1994; 120: 495-503.

Rao MS, Anderson DJ. Immortalization and controlled in vitro differentiation of murine multipotent neural crest stem cells. J Neurobiol 1997; 32: 722-746. 
Rollhauser-ter Horst J. Artificial neural crest formation in amphibia. Anat Embryol 1979; 157: 113-120.

Rollhauser-ter Horst J. Artificial neuron induction in amphibia. Anat Embryol 1977; 151: 309-316.

Sadaghiani B, Thiébaud CH. Neural crest development in the Xenopus laevis embryo, studied by interspecific transplantation and scanning electron microscopy. Dev Biol 1987; 124: 91-110.

Saint-Jeannet JP, He X, Varmus HE, Dawid IB. Regulation of dorsal fate in the neuraxis by Wnt1 and Wnt-3a. Proc Natl Acad Sci USA 1997; 94: 13713-13718.

Sanes JR, Rubinstein JLR, Nicolas JF. Use of a re-combinant retrovirus to study postimplantation cell lineage in mouse embryos. Embo J 1986; 5: 3133-3142.

Sang H. Prospects for transgenesis in the chick. Mech Dev 2004; 121: 1179-1186.

Santagati F, Rijli FM. Cranial neural crest and the building of the vertebrate head. Nature Rev Neurosci 2003; 4: 806-818.

Sasaki R, Aoki S, Yamato M, Uchiyama H, Wada K, Okano T, Ogiuchi H. Neurosphere generation from dental pulp of adult rat incisor. Eur J Neurosci 2008; 27: 538-548.

Sasaki R, Aoki S, Yamato M, Uchiyama H, Wada K, Okano T, Ogiuchi H. Tubulation with dental pulp cells promotes facial nerve regeneration in rats. Tissue Eng Part A 2008; 14: 1141-1147.

Sauer B. Functional expression of the Cre-lox site-specific recombination system in the yeast Saccharomyces cerevisiae. Mol Cell Biol 1987; 7: 2087-2096.

Sauer B. Inducible gene targeting in mice using the Cre/lox system. Methods 1998; 14 : 381-392.

Schilling TF, Kimmel CB. Segment and cell type lineage restrictions during pharyngeal arch development in the zebrafish embryos during pharyngeal arch development in the zebrafish embryo. Development.1994; 120: 483-494.

Schneider RA, Helms JA. The cellular and molecular origins of beak morphology. Science 2003; 299(5606): 565-568.

Sela-Donenfeld D, Kalcheim C. Inhibition of noggin expression in the dorsal neural tube by somitogenesis: a mechanism for coordinating the timing of neural crest emigration. Development 2000; 127: 4845-4854. 
Shoval I, Ludwig A, Kalcheim C. Antagonistic roles of full-length N-cadherin and its soluble BMP cleavage product in neural crest delamination. Development 2007; 134 : 491-501.

Sieber-Blum M, Cohen AM. Clonal analysis of quail neural crest cells: they are pluripotent and differentiate in vitro in the absence of noncrest cells. Dev Biol 1980; 80: 96-106.

Sodek J, McKee MD. Molecular and cellular biology of alveolar bone. Periodontol 2000; 24: 99-126.

Sonoyama W, Liu Y, Yamaza T, Tuan RS, Wang S, Shi S, Huang GT. Characterization of the apical papilla and its residing stem cells from human immature permanent teeth: a pilot study. J Endod 2008; 34: 166-171.

Stemple DL, Anderson DJ. Isolation of a stem cell for neurons and glia from the mammalian neural crest. Cell 1992. 11; 71: 973-985.

Stemple DL, Anderson DJ. Lineage diversification of the neural crest in vitro investigations. Dev Biol 1993; 159: 12-23.

Stevens A, Zuliani T, Olejnik C, LeRoy H, Obriot H, Kerr-Conte J, Formstecher P, Bailliez Y, Polakowska RR. Human dental pulp stem cells differentiate into neural crest-derived melanocytes and have label-retaining and sphere-forming abilities. Stem Cells Dev 2008; 17: 1175-1184.

Tanaka E, Detamore MS, Mercuri LG. Degenerative disorders of the temporomandibular joint: etiology, diagnosis, and treatment. J Dent Res 2008; 87: 296307.

Taneyhill LA, Bronner-Fraser M. Recycling signals in the neural crest. J Biol 2006; 4: 10.1-5.

Thesleff I, Sharpe P. Signaling networks regulating dental development. Mech Dev 1997; 67: 111-123.

Thesleff I, Vaatokari A, Partanen AM. Regulation of organogenesis: common molecular pathways regulating the development of teeth and other organs. Int J Dev Biol 1995; 39: 35-50.

Thomas S, Thomas M, Wincker P, Babarit C, Xu P Speer MC, Munnich A, Lyonnet S, Vekemans M, Etchevers HC. Human neural crest cells display molecular and phenotypical hallmarks of stem cells. Hum Mol Genet 2008; 17: 3411-3425. 
Tomita Y, Matsumura K, Wakamatsu Y, Matsuzaki Y,Shibuya I, Kawaguchi H, Ieda M, Kanakubo S, Shimazaki T, Ogawa S, Osumi N, Okano H, Fukuda K. Cardiac neural crest cells contribute to the dominant multipotential stem cell in the heart. J Cell Biol 2005; 70: 1135-1146.

Trainor PA, Krumlauf R. Patterning the cranial neural crest: hindbrain segmentation and Hox gene plasticity. Nat Rev Neurosci 2000; 1: 116-124.

Trainor PA, Sobieszczuk D, Wilkinson D, Krumlauf R. Signaling between the hindbrain and paraxial tissues dictates neural crest migration pathways. Development 2002; 129 : 433-442.

Waddington RJ, Youde SJ, Lee CP, Sloan AJ. Isolation of distinct progenitor stem cell populations from dental pulp. Cells Tissues Organs 2009; 189: 268-274.

Weston JA. A radioautographic analysis of the migration and localization of trunk neural crest cells in the chick. Dev Biol 1963; 6: 279-310.

Widera D, Grimm WD, Moebius JM, Mikenberg I, Piechaczack C, Grassmannm G, Wolff NA, Thévenod F, Kaltschmidt C, Kaltschmidt B. Highly efficient neural differentiation of human somatic stem cells isolated by minimally invasive periodontal surgery. Stem Cells Dev 2007; 16: 447-460.

Wilson YM, Richards KL, Ford-Perriss ML, Panthier JJ, Murphy M. Neural crest cell lineage segregation in the mouse neural tube. Development 2004; 131: 6153-6162.

Wu J, Saint-Jeannet JP, Klein PS. Wnt-frizzled signaling in neural crest formation. Trends Neurosci 2003; 26: 40-45.

Yelick PC, Schilling TF. Molecular dissection of craniofacial development using zebrafish. Crit Rev Oral Biol Med 2002; 13: 308-322.

Yu J, Wang Y, Deng Z, Tang L, Li Y, Shi J, Jin Y. Odontogenic capability: bone marrow stromal stem cells versus dental pulp stem cells. Biol Cell 2007; 99: 465-474.

Zhang J, Duan X, Zhang H, Deng Z, Zhou Z, Wen N, Smith AJ, Zhao W, Jin Y. Isolation of neural crest-derived stem cells from rat embryonic mandibular processes. Biol Cell 2006; 98: 567-575.

Zhang Y, Wang S, Song Y, Han J, Chai Y, Chen Y. Timing of odontogenic neural crest cell migration and tooth-forming capability in mice. Dev Dyn 2003; 226: 713-718. 


\section{VITA}

Dr. Vinay Jain was born on May 25, 1979. He received his doctoral degree in dentistry (Bachelor of Dental Surgery) from the Government Dental College and Hospital, Mumbai, India, in 2002. He also received a M.S. degree in Environmental Sciences from Florida A \& M University in 2007. He was accepted into the Advanced Prosthodontics Program at University of Tennessee Health Science Center in 2007. Dr. Jain is currently a third year resident, specializing in fixed and removable prosthodontics at UTHSC. He will be finishing his Master of Dental Science degree from the University of Tennessee. He is a current member of the American College of Prosthodontists. 